\title{
Assessing the sustainability of Best Available Techniques (BAT): methodology and application in the ceramic tiles industry
}

\author{
V. Ibáñez-Forés ${ }^{a, b, 1}$, M.D. Bovea ${ }^{a}$, A. Azapagic ${ }^{\text {b,* }}$ \\ ${ }^{a}$ Department of Mechanical Engineering and Construction, Universitat Jaume I, Castellón, Spain \\ ${ }^{\mathrm{b}}$ School of Chemical Engineering and Analytical Science, The University of Manchester, UK
}

\section{A R T I C L E I N F O}

\section{Article history:}

Received 9 July 2012

Received in revised form

8 January 2013

Accepted 16 January 2013

Available online 4 February 2013

\section{Keywords:}

Best Available Technology (BAT)

Ceramic tiles industry

Eco-efficiency

LCA

Sustainability assessment

\begin{abstract}
A B S T R A C T
This paper presents a methodology for identifying sustainable and most appropriate BAT for a given industrial installation and sector. The methodology involves identification of environmental hot spots from an installation by using life cycle assessment (LCA) to guide the selection of candidate BAT options for targeting the hot spots. The selected BAT options are then assessed on sustainability using relevant environmental, economic, technical and social indicators. This enables benchmarking of different options and selection of the most appropriate alternative(s) for the system of interest. The application of the approach is illustrated by a case study of ceramic tiles produced in Spain. The results indicate that firing and drying are the hot spots for most sustainability impacts considered. To target these, 11 BAT options used in 13 alternative configurations of the manufacturing process have been considered and assessed on sustainability. The results suggest that the most sustainable BAT options for the ceramic tiles industry, both environmentally and economically, include heat recovery from the flue gas and its clean-up with $\mathrm{CaCO}_{3}$ and/or $\mathrm{Ca}(\mathrm{OH})_{2}$. Depending on the configuration, cost savings of up to $30 \%$ and environmental improvements of over $95 \%$ can be achieved with these BAT options.
\end{abstract}

(c) 2013 Elsevier Ltd. All rights reserved.

\section{Introduction}

On 6 January 2011, the EU Directive on Industrial Emissions (IED) came into force (EC, 2010), amalgamating and replacing the following seven directives on:

- integrated pollution prevention and control;

- large combustion plants;

- waste incineration;

- solvent emissions; and

- titanium dioxide (three directives related to disposal, monitoring \& surveillance and programs for pollution reduction).

Among the main modifications aimed at reducing the environmental impacts caused by industrial activities, the Directive strengthens the application of Best Available Techniques (BAT) in the EU across a range of sectors, also establishing Emission Limit Values (ELV) for different polluting substances.

\footnotetext{
* Corresponding author.

E-mail address: adisa.azapagic@manchester.ac.uk (A. Azapagic).

1 Visiting scientist.
}

BAT span both the type of technology used and the way in which an installation is designed, built, maintained, operated and decommissioned (EC, 2010). The term 'available' refers to whether the BAT is reasonably accessible to the operator and its implementation is economically and technically feasible. Finally, the term 'best' means 'providing a high level of protection of the environment as a whole'. Thus BAT play a key role in improving the industrial sustainability through higher energy efficiency, reduced pollution and related environmental and economic benefits. The main criteria for choosing a BAT include the consumption and nature of raw materials, energy efficiency, the use of low-waste technology and less hazardous substances as well as the cost of its implementation.

To help companies identify BAT, the European Commission has drawn up so called 'reference documents' for different industrial sectors; these are known as BREFs. However, whilst helpful, the BREFs often include a myriad of BAT options, making it difficult to choose amongst the alternatives as different factors determine the viability of a BAT for different companies. These include internal drivers such as economic and technical as well as external aspect such as social or legal requirements. Therefore, there is a need for methodologies and tools to help companies select BAT that are appropriate for their conditions while at the same time complying 
with the Directive. This has also been recognised by other authors (e.g. Nicholas et al., 2000; Geldermann and Rentz, 2001; Kocaoglu et al., 2001; Derden et al., 2002; Doukas et al., 2006; Guo et al., 2006; Shehabuddeen et al., 2006; Mavrotas et al., 2007; Georgopoulou et al., 2008; Schollenberger et al., 2008; GómezLópez et al., 2009; Karavanas et al., 2009; Pilavachi et al., 2009; Lin and Shen, 2010; García and Caballero, 2011; Giner-Santonja et al., 2012; Liu and Wen, 2012).

Although BAT must protect the environment as a 'whole', the IED does not require the use of full life cycle assessment (LCA) to assess their environmental performance from 'cradle to grave'. This means that, while BAT aim to reduce certain direct and indirect emissions related to an installation, the full life cycle emissions and impacts are not considered. Therefore, without the use of LCA it is not possible to identify environmentally most sustainable option(s) among different BAT alternatives as some impacts could either be missed out or underestimated (Nicholas et al., 2000).

This paper proposes a methodology for identifying sustainable BAT by considering in a systematic way a range of environmental, economic and social requirements specified in the IED and the BREFs. 'Sustainable BAT' is defined here as BAT with the lowest environmental, economic and social impacts compared to alternatives. It also shows how LCA can be integrated within such a methodology to ensure that the environment is protected as a 'whole' as required by the Directive, preventing the shifting of environmental burdens upstream or downstream from the installation. The application of the methodology is illustrated by a case study of ceramic tiles produced in Spain with the aim of providing a practical guidance for improving the level of sustainability of the tiles manufacturing process through the selection of most appropriate BAT for this sector. The methodology is detailed in the next section, followed by the case study in Section 3. The conclusions are drawn in Section 4.

\section{Methodology}

As illustrated in Fig. 1, the methodology for identifying sustainable BAT developed in this work consists of four stages:

1. definition of the baseline system without application of BAT and estimation of life cycle environmental impacts to identify the need for different BAT (baseline scenario);
2. identification of candidate BAT and possible system configurations with the application of BAT (alternative scenarios);

3. selection of environmental, economic, technical and social indicators followed by sustainability assessment and benchmarking of candidate BAT options and alternative scenarios;

4. selection of most sustainable BAT.

These stages are described below.

\subsection{Definition of baseline scenario and estimation of life cycle environmental impacts}

In the first stage, the baseline system configuration without application of BAT is defined, taking into account inputs into and outputs from the system. This is followed by the estimation of both the direct emissions of the 'polluting substances' from the installation as required by the IED (EC, 2010) as well as the life cycle environmental impacts using LCA. This information is used to establish the baseline environmental performance of the system and to identify the 'hot spots' that contribute most to the impacts so that the candidate BAT can be identified in the next stage of the methodology.

\subsection{Candidate BAT and alternative scenarios}

For any system, there may be a wide range of candidate BAT. Their initial choice will be guided by the IED requirements (see Section 1), targeting the environmental hot spots identified in the previous stage. In addition to the environmental impacts, the choice will depend on other factors such as costs, accessibility, etc.

Once the candidate BAT have been chosen, the next step is to consider how they could be integrated into the manufacturing process. There could be numerous alternative ways to incorporate BAT into the system, depending on the specific characteristics of the installation. For example, applying a BAT to increase the energy efficiency of the system by recovering heat from flue gases before the clean-up may affect the performance of the clean-up BAT by reducing the dew point of acid gases (e.g. $\mathrm{SO}_{2}$ ), thus damaging the equipment due to the formation of acid. Therefore, the type and location of each BAT are important and must be assessed carefully. To enable this, a range of alternative scenarios is defined in this stage, considering different combinations of BAT options and their optimum placement within the installation.

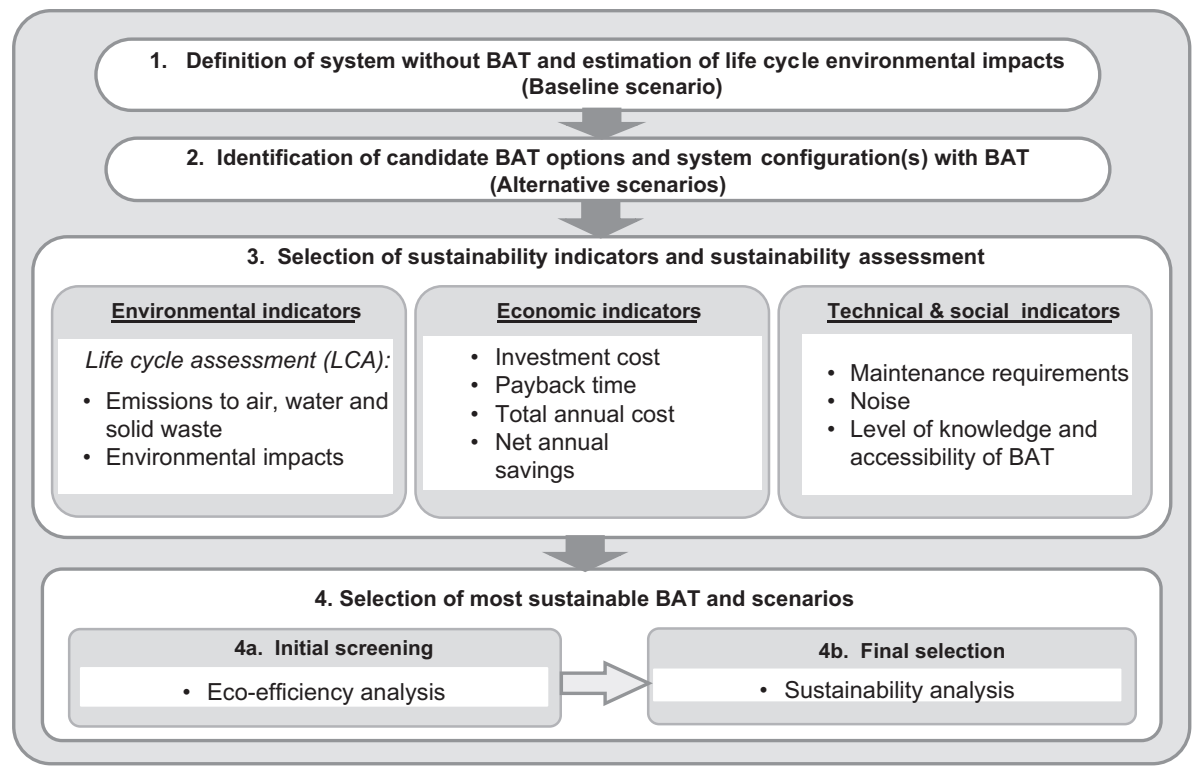

Fig. 1. Methodology for identifying sustainable BAT. 


\subsection{Selection of sustainability indicators and sustainability assessment}

The chosen BAT options and the alternative scenarios are assessed on sustainability in this stage, using relevant environmental, economic, technical and social indicators. This will enable benchmarking of different options amongst each other as well as against the baseline scenario, helping to identify the most sustainable options.

\subsubsection{Environmental indicators}

As in the baseline scenario, LCA is used to assess the environmental performance of different BAT options and alternative scenarios. Therefore, the environmental indicators are those typically used in LCA and include, but are not limited to, the depletion of abiotic resources, global warming, ozone layer depletion, acidification, eutrophication and human toxicity (for definitions, see e.g. Guinée (2002)).

\subsubsection{Economic indicators}

A number of different indicators can be used to assess the economic sustainability of BAT. Following the guidelines in the BREF on Economics and Cross-Media Effects (EC, 2006a), four economic indicators are considered here for each BAT and scenario: investment costs, pay-back times, total annual costs and net annual savings. The pay-back time is defined as the period of time needed to recover the initial investment. According to the BAT costing methodology in EC (2006a), an investment is considered profitable when the pay-back time is equal to or shorter than three years.

Total annual cost (TAC) of a BAT comprises the annual capital, operating and maintenance costs and it can be calculated as follows (EC, 2006a):

$\mathrm{TAC}=C_{0}\left[\frac{r(1+r)^{n}}{(1+r)^{n}-1}\right]+\mathrm{OMC} \quad(€ / \mathrm{yr})$

where:

$$
\begin{aligned}
& C_{0}-\text { investment cost in the base year }(€ / \mathrm{yr}) \\
& r-\text { discount (interest) rate }(-) \\
& n-\text { lifetime of equipment/plant (years) } \\
& \text { OMC - operating and maintenance costs }(€ / \mathrm{yr})
\end{aligned}
$$

The net annual savings (NAS) represent the difference between the avoided costs (AC) and TAC:

$\mathrm{NAS}=\mathrm{AC}-\mathrm{TAC} \quad(€ / \mathrm{yr})$

The AC represent cost savings in raw materials, energy, labour, etc. owing to the implementation of BAT and are estimated as:

$A C=\sum_{i=1}^{R}\left[\left(R C_{i o}-R C_{i}\right) \times M P_{i}\right] \quad \forall\left(R C_{i o}-R C_{i}\right) \geq 0 \quad(€ / \mathrm{yr})$

where:

$R$ - total number of resources (energy, water, raw material, etc.) $\mathrm{RC}_{i \mathrm{o}}$ - annual consumption of resource $i$ before the application of BAT (baseline scenario)

$\mathrm{RC}_{i}$ - annual consumption of resource $i$ after the application of BAT (alternative scenario)

$\mathrm{MP}_{i}$ - market price of resource $i$

\subsubsection{Technical and social indicators}

Based on the BAT guidelines (EC, 2006a, 2010), the following technical and social indicators are considered here:

- maintenance requirements;

- noise; and

- level of knowledge about and accessibility of BAT.

The first indicator considers the requirements for maintenance, including the frequency and complexity involved as well as the related staff skills and training needed. As there is no agreed methodology on how to calculate this indicator, a qualitative scoring method is proposed here, with the scores ranging from 1 , indicating low maintenance needs, to 4 , signifying very high requirements (see Table 1 ). A similar approach is proposed for noise: the scores range from -1 for noise reduction by a BAT to 0 for a small or no change ( $<3 \mathrm{dBA}$ ) to 1 for increased noise levels due to the application of BAT. If more than one BAT is considered within a scenario, then the overall score for each of the two indicators is calculated as the sum of the scores for the individual BAT options.

In addition to these, it is also important that the operator has a certain level of knowledge about the BAT and that the BAT is reasonably accessible and/or applied relatively widely in industry (EC, 2010). Similar to the other two criteria, it is also proposed to measure this indicator by using a qualitative scoring method. As shown in Table 1, the scores range from 1 for no knowledge/ application to 4 for high levels of knowledge and wide-spread application in industry. In this case, if there are two or more BAT in a scenario, the overall score is calculated as the average of the scores for all the BAT options that make up that scenario.

\subsection{Selection of most sustainable BAT and scenarios}

Based on the sustainability assessment carried out in the previous stage, this step of the methodology involves identification and selection of the most sustainable BAT option(s) and scenario(s). To aid the selection process, an initial screening is carried out by comparing the scenarios on their environmental and economic performance or 'eco-efficiency'. As a result, less efficient options are discarded and the remaining options are then compared on all the sustainability criteria considered within this methodology. This is described briefly below.

\subsubsection{Initial screening: eco-efficiency analysis}

For the purposes of initial screening, the alternative scenarios are compared for the net annual savings (NAS) and their emission reduction potentials (ERP) to the baseline scenario. NAS is chosen for consideration because it encapsulates all other economic criteria considered here. The ERP represent the potential of the alternative scenarios to reduce the emissions compared to the baseline scenario and are considered for all the emissions and related impacts assessed by LCA. Both NAS and ERP are expressed relative to the baseline scenario.

\begin{tabular}{|c|c|c|c|c|c|}
\hline Maintenance & Score & Noise & Score & Knowledge/accessibility & Score \\
\hline Low & 1 & Reduction & -1 & $\begin{array}{l}\text { No application/no } \\
\text { knowledge }\end{array}$ & 1 \\
\hline Medium & 2 & $\begin{array}{l}\text { Small or } \\
\text { no change } \\
(<3 \mathrm{dBA})\end{array}$ & 0 & $\begin{array}{l}\text { Some application/some } \\
\text { knowledge }\end{array}$ & 2 \\
\hline High & 3 & Increase & 1 & $\begin{array}{l}\text { Reasonable application/ } \\
\text { general knowledge }\end{array}$ & 3 \\
\hline Very high & 4 & & & $\begin{array}{l}\text { Wide-spread application/ } \\
\text { extensive knowledge }\end{array}$ & 4 \\
\hline
\end{tabular}

Table 1

Scores for different maintenance requirements, noise and level of knowledge/ accessibility of BAT. 
Fig. 2 shows an example eco-efficiency graph used for the screening purposes, with the $x$-axis representing NAS scores and the $y$-axis the ERP. The NAS scores are determined on a case by case basis, depending on the level of savings and could range from -1 denoting that the costs are higher than the savings, to 5, which would correspond to the highest NAS. As shown, the graph is divided into four parts, each indicating different levels of environmental and economic efficiency. For example, the top right-hand square represents the maximum eco-efficiency with high ERP and NAS while the diagonally opposite space corresponds to the minimum eco-efficiency. For an option to be considered further, in the approach adopted here, it has to fall in the maximum eco-efficiency square for at least one of the environmental emissions or impacts. Otherwise, it is discarded as eco-inefficient. The lines that divide the eco-efficiency space into four parts have to be defined for each case separately. For NAS, the vertical line is drawn through the middle of the scale, which in the example shown in Fig. 2 is equal to 2. The horizontal line is positioned relative to the scenario with the highest ERP compared to the baseline scenario. The approach adopted here is based on the $50 \%$ cut-off rule, which means that the minimum acceptable ERP for all other options is $50 \%$ relative to the top-performing option. For example, as shown in Fig. 2, if scenario A achieves a $70 \%$ reduction of an emission or impact relative to the baseline scenario, then all other options must achieve at least 50\% of that, i.e. 35\% relative to the baseline scenario. Therefore, the ERP dividing line is set at the level of $35 \%$ on the $y$-axis.

\subsubsection{Sustainability analysis}

Once the less eco-efficient scenarios have been screened out, the remaining options are compared for all the sustainability criteria considered. Owing to the disparate nature of the indicators as well as the different units in which they are expressed, they first need to be normalised to enable cross-comparisons. The following approach has been adopted for these purposes (Afgan and Carvalho, 2002; Sadiq et al., 2005; Pilavachi et al., 2006; Wang et al., 2008):

If a higher value of indicator is better : $z_{i j}=\frac{x_{i j}-x_{i \min }}{x_{i \max }-x_{i \min }}$

If a lower value of indicator is better : $z_{i j}=\frac{x_{i \max }-x_{i j}}{x_{i \max }-x_{i \min }}$

where:

$i=1,2, \ldots, n-$ number of sustainability indicators

$j=1,2, \ldots, m-$ number of alternative scenarios

$z_{i j}=$ normalised value of $i$ th indicator for the $j$ th scenario

$x_{i j}=$ value of $i$ th indicator for the $j$ th scenario

$x_{i \min }=\min \left(x_{i 1}, x_{i 2}, \ldots, x_{i \mathrm{~m}}\right)$ and $x_{i \max }=\max \left(x_{i 1}, x_{i 2}, \ldots, x_{i \mathrm{~m}}\right)-$ minimum and maximum values of $i$ th indicator for all scenarios.
The alternatives are then compared for the normalised values for each indicator. Since there are a number of different criteria, choosing the 'best' option will often be difficult. As an aid in this process, the results can be plotted on a 'spider' graph showing all the indicators at the same time and indicating the 'sustainability footprint' of each alternative - the smaller the footprint, the better the alternative. This approach is helpful if all sustainability criteria are considered to be of equal importance. However, this will rarely be the case as some indicators will be more important than the others. In such cases, multi-criteria decision analysis can be used to take into account different preferences for different sustainability criteria (see e.g. Azapagic and Perdan, 2005a,b).

The above methodology has been applied to a case study of ceramic tiles with the aim of demonstrating its application but also to help identify the most sustainable BAT for this sector. This is discussed in the rest of the paper.

\section{Case study: the ceramic tiles sector}

The manufacture of ceramic tiles is subject to the IED (EC, 2010) for installations producing over 75 tonnes per day and/or with a kiln capacity exceeding $4 \mathrm{~m}^{3}$ and with a setting density per kiln exceeding $300 \mathrm{~kg} / \mathrm{m}^{3}$. The case study considered here is based on 20 manufacturing sites in Spain, all of which are subject to the IED. Further detail on the manufacturing sites can be found in IbañezForés et al. (2011). Here, we provide an overview of the manufacturing process and the data used for the case study.

As shown in Fig. 3, the tile manufacturing process consists of seven stages: clay preparation, pressing, drying, glazing, firing, packing and palletising, and storage. The clay preparation stage involves loading of clay into silos and its transport to the pressing line. There, the atomised clay is mechanically compressed by hydraulic presses into a desired shape. The shaped clay is then dried to reduce its moisture content before the glazing stage, where the tiles are decorated by applying glazes on the surface. This is followed by firing in single-deck roller-kilns to set the tiles. The temperature and duration of firing determines the properties of the tiles such as hardness and impact resistance. The tiles are then sorted into different quality categories before being packed, palletised and stored in a warehouse.

The baseline (without BAT) and alternative scenarios (with BAT) are described in the following sections. In all cases, the analysis is based on the functional unit defined as ' $1 \mathrm{~m}^{2}$ of tiles' and the system boundary is from 'cradle to gate'.

\subsection{Definition of baseline scenario and estimation of life cycle environmental impacts}

The baseline scenario corresponds to the system shown in Fig. 3 (without any BAT installed). The inventory data used for

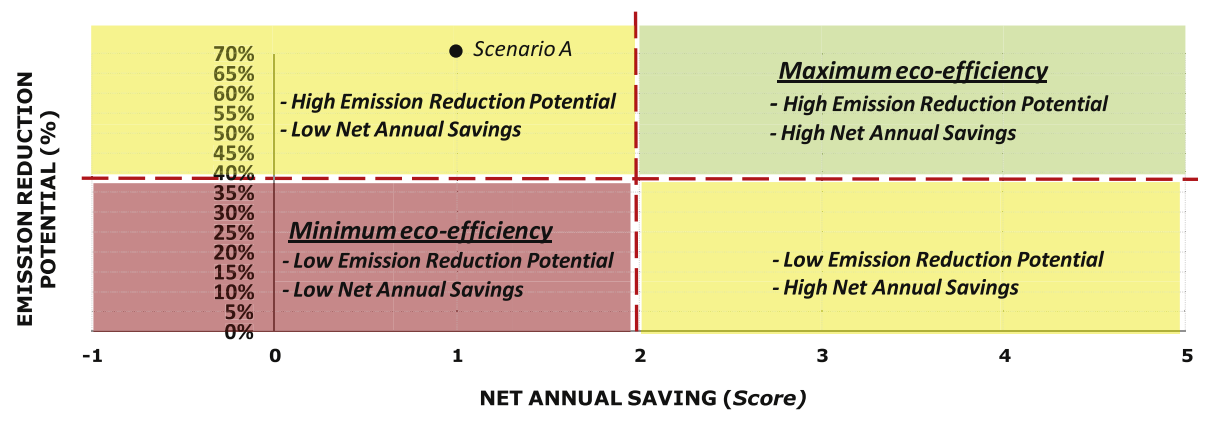

Fig. 2. Eco-efficiency analysis: an example. 


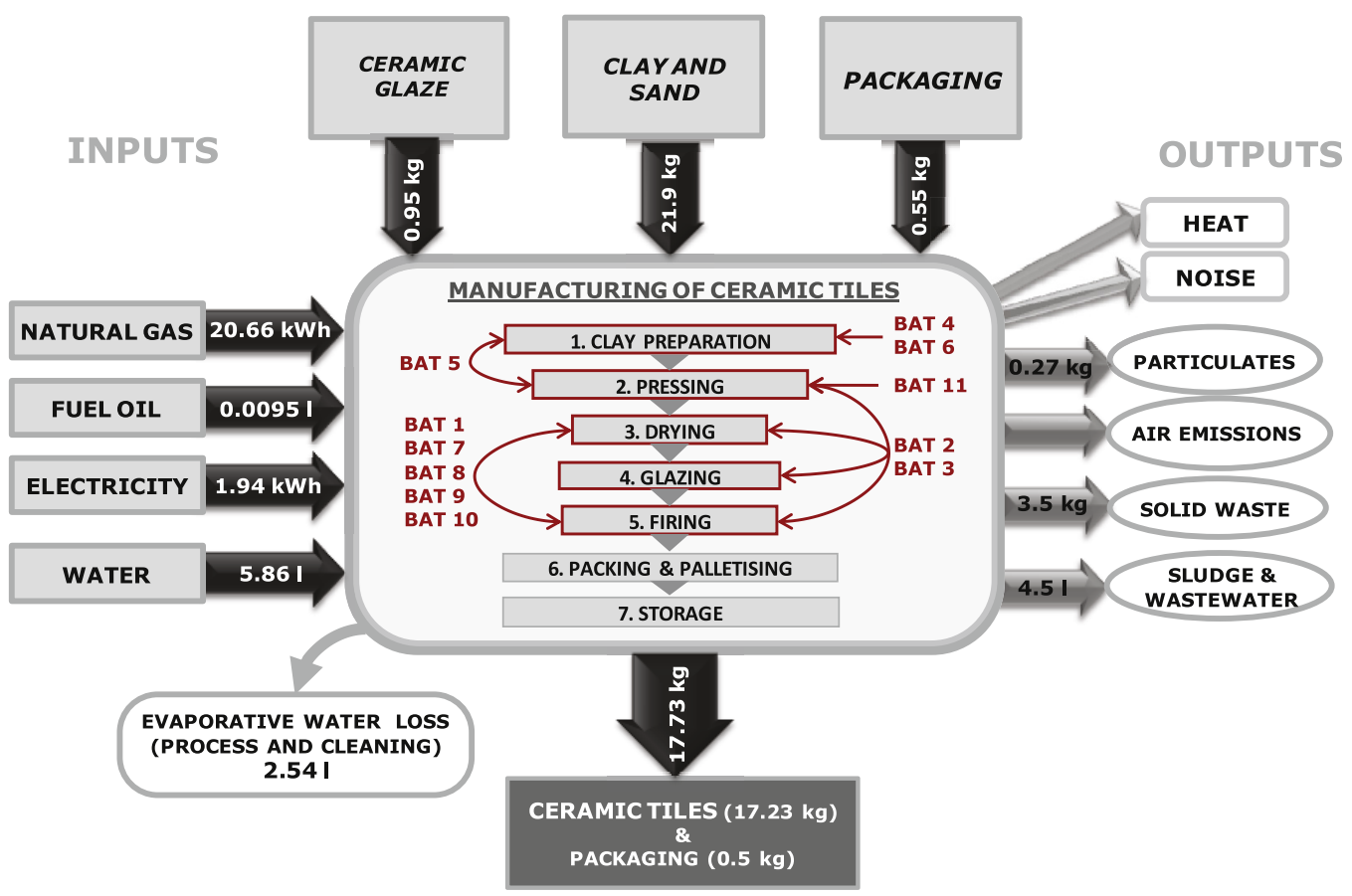

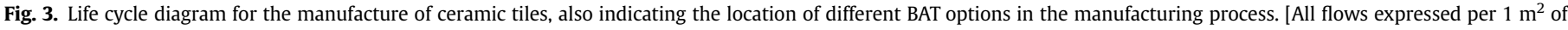
tiles. The life cycles of all inputs and their impacts are included in the analysis.].

the estimation of the life cycle environmental impacts are summarised in Table 2 and represent the average data for 20 manufacturing sites in Spain (for details on the sites, see Ibañez-Forés et al., 2011).
Following the recommendations by ISO 14025 (ISO, 2006) on environmental product declarations (EPDs) and relevance of different environmental impacts to the system considered (IbañezForés et al., 2011), the categories considered here are: abiotic

Table 2

Baseline scenario: inventory data for the production of ceramic tiles.

\begin{tabular}{|c|c|c|c|c|c|c|c|c|c|}
\hline & Clay preparation & Pressing & Drying & Glazing & Firing & Packing \& palletising & Storage & Other activities ${ }^{\mathrm{a}}$ & Total \\
\hline \multicolumn{10}{|l|}{ Inputs } \\
\hline Electricity $\left(\mathrm{kWh} / \mathrm{m}^{2}\right)$ & 0.12 & 0.48 & 0.12 & 0.33 & 0.41 & 0.07 & 0.08 & 0.33 & 1.94 \\
\hline Fuel oil $\left(\mathrm{l} / \mathrm{m}^{2}\right)$ & 0 & 0 & 0 & 0 & 0 & 0 & 0.0095 & 0 & 0.0095 \\
\hline Natural gas $\left(\mathrm{kWh} / \mathrm{m}^{2}\right)$ & 0 & 0 & 6.70 & 0 & 14.00 & 0 & 0 & 0 & 20.66 \\
\hline Water $\left(1 / \mathrm{m}^{2}\right)$ & 0.76 & 0.07 & 0 & 4.29 & 0 & 0 & 0 & 0.74 & 5.86 \\
\hline Clay and sand $\left(\mathrm{kg} / \mathrm{m}^{2}\right)$ & 21.90 & 0 & 0 & 0 & 0 & 0 & 0 & 0 & 21.90 \\
\hline Ceramic glaze $\left(\mathrm{kg} / \mathrm{m}^{2}\right)$ & 0 & 0 & 0 & 0.95 & 0 & 0 & 0 & 0 & 0.95 \\
\hline Machine oil $\left(\mathrm{kg} / \mathrm{m}^{2}\right)$ & 0 & 0.0004 & 0 & 0 & 0 & 0.0004 & 0.0004 & 0 & 0.0012 \\
\hline Cardboard boxes $\left(\mathrm{kg} / \mathrm{m}^{2}\right)$ & 0 & 0 & 0 & 0 & 0 & 0.11 & 0 & 0 & 0.11 \\
\hline Pallets $\left(\mathrm{kg} / \mathrm{m}^{2}\right)$ & 0 & 0 & 0 & 0 & 0 & 0.31 & 0 & 0 & 0.31 \\
\hline Plastic bags $\left(\right.$ LDPE $\left.^{\mathrm{b}}\right)\left(\mathrm{kg} / \mathrm{m}^{2}\right)$ & 0 & 0 & 0 & 0 & 0 & 0.01 & 0 & 0 & 0.01 \\
\hline Plastic packaging $\left(\mathrm{PP}^{\mathrm{c}}\right)\left(\mathrm{kg} / \mathrm{m}^{2}\right)$ & 0 & 0 & 0 & 0 & 0 & 0.07 & 0 & 0 & 0.07 \\
\hline Plastic strips $\left(\mathrm{kg} / \mathrm{m}^{2}\right)$ & 0 & 0 & 0 & 0 & 0 & 0.004 & 0 & 0 & 0.004 \\
\hline Adhesives $\left(\mathrm{kg} / \mathrm{m}^{2}\right)$ & 0 & 0 & 0 & 0 & 0 & 0.05 & 0 & 0 & 0.05 \\
\hline \multicolumn{10}{|l|}{ Outputs } \\
\hline PM10 $\left(\mathrm{kg} / \mathrm{m}^{2}\right)$ & 0.11 & 0.15 & 0.0010 & 0.0007 & 0.005 & 0 & 0 & 0 & 0.27 \\
\hline $\mathrm{NO}_{x}\left(\mathrm{~kg} / \mathrm{m}^{2}\right)$ & 0 & 0 & 0.001 & 0 & 0.008 & 0 & 0 & 0 & 0.01 \\
\hline $\mathrm{SO} x\left(\mathrm{~kg} / \mathrm{m}^{2}\right)$ & 0 & 0 & 0.001 & 0 & 0.02 & 0 & 0 & 0 & 0.02 \\
\hline $\mathrm{CO}_{2}\left(\mathrm{~kg} / \mathrm{m}^{2}\right)$ & 0 & 0 & 1.29 & 0 & 3.14 & 0 & 0 & 0 & 4.43 \\
\hline $\mathrm{CO}\left(\mathrm{kg} / \mathrm{m}^{2}\right)$ & 0 & 0 & 0.005 & 0 & 0.0009 & 0 & 0 & 0 & 0.005 \\
\hline $\mathrm{HF}\left(\mathrm{kg} / \mathrm{m}^{2}\right)$ & 0 & 0 & 0 & 0 & 0.003 & 0 & 0 & 0 & 0.003 \\
\hline $\mathrm{HCl}\left(\mathrm{kg} / \mathrm{m}^{2}\right)$ & 0 & 0 & 0 & 0 & 0.009 & 0 & 0 & 0 & 0.009 \\
\hline $\mathrm{B}\left(\mathrm{kg} / \mathrm{m}^{2}\right)$ & 0 & 0 & 0 & 0 & 0.00005 & 0 & 0 & 0 & 0.00005 \\
\hline $\mathrm{Pb}\left(\mathrm{kg} / \mathrm{m}^{2}\right)$ & 0 & 0 & 0 & 0 & 0.00002 & 0 & 0 & 0 & 0.00002 \\
\hline Waste water $\left(1 / \mathrm{m}^{2}\right)$ & 0 & 0 & 0 & 3.89 & 0 & 0 & 0 & 0.61 & 4.50 \\
\hline Hazardous waste $\left(\mathrm{kg} / \mathrm{m}^{2}\right)$ & 0.000003 & 0.001 & 0.000003 & 0.0010 & 0 & 0 & 0.0009 & 0.0003 & 0.0033 \\
\hline Non-hazardous waste $\left(\mathrm{kg} / \mathrm{m}^{2}\right)$ & 0.0004 & 0.25 & 0.0004 & 2.08 & 0.06 & 0.03 & 0.04 & 1.03 & 3.49 \\
\hline \multicolumn{10}{|l|}{ Additional data } \\
\hline Noise (dBA) & 79.2 & 86.8 & 80 & 79.9 & 78.3 & 74.5 & 68.1 & 58.9 & - \\
\hline Temperature $\left({ }^{\circ} \mathrm{C}\right)$ & - & 30 & 190 & 30 & 300 & - & - & - & - \\
\hline Flue gas $\left(\mathrm{Nm}^{3} / \mathrm{h}\right)$ & - & 70,877 & 42,448 & 3069 & 68,977 & - & - & - & 185,371 \\
\hline
\end{tabular}

a Includes maintenance, cleaning, operation of premises, etc.

b Low density polyethylene.

c Polypropylene. 
resource depletion, acidification, eutrophication, global warming, ozone layer depletion, photochemical oxidants and human toxicity. The LCA software SimaPro v7.3.2 (PRe Consultants, 2011) and the CML 2001 method (Guinée, 2002) have been used to estimate the life cycle impacts. The life cycle inventory data for the inputs shown in Fig. 3 have been sourced from Ecoinvent (2010).

The results are shown in Fig. 4, indicating that firing and drying are the hot spots in the system for most environmental impacts considered. This is due to the high energy demand in these stages as well as the emissions of acid gases. Furthermore, clay preparation and pressing are also significant for human toxicity, mainly due to the emissions of particulates (as also shown in Table 2). These results are congruent with the data shown in Table 2, which indicate that the use of resources and direct emissions of different substances are highest in these stages. Note that the life cycle impacts associated with the fuels and raw materials have been allocated to the unit operations in the manufacturing process in proportion to their respective usage. The impacts from the emissions and wastes are either directly measured or estimated in
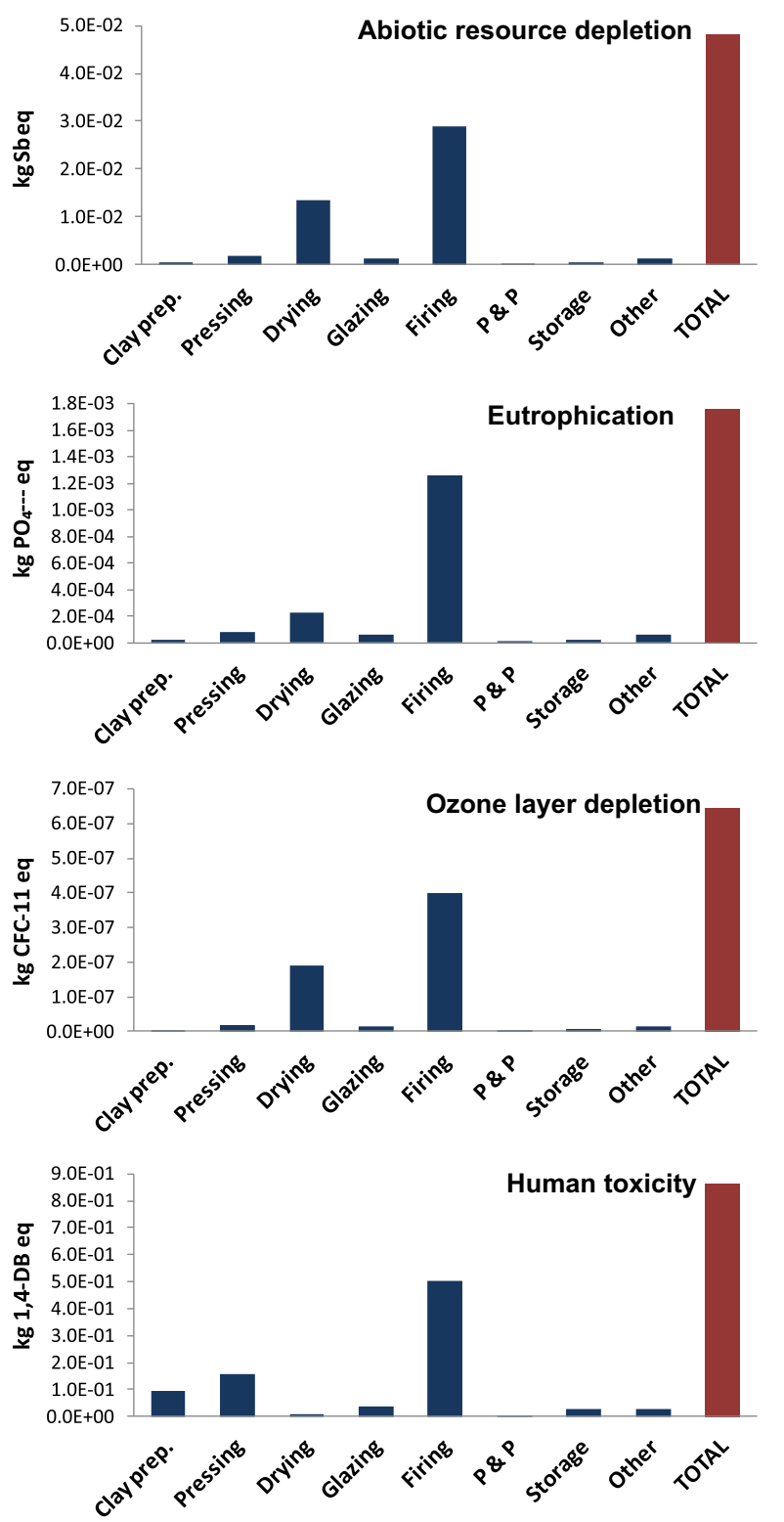
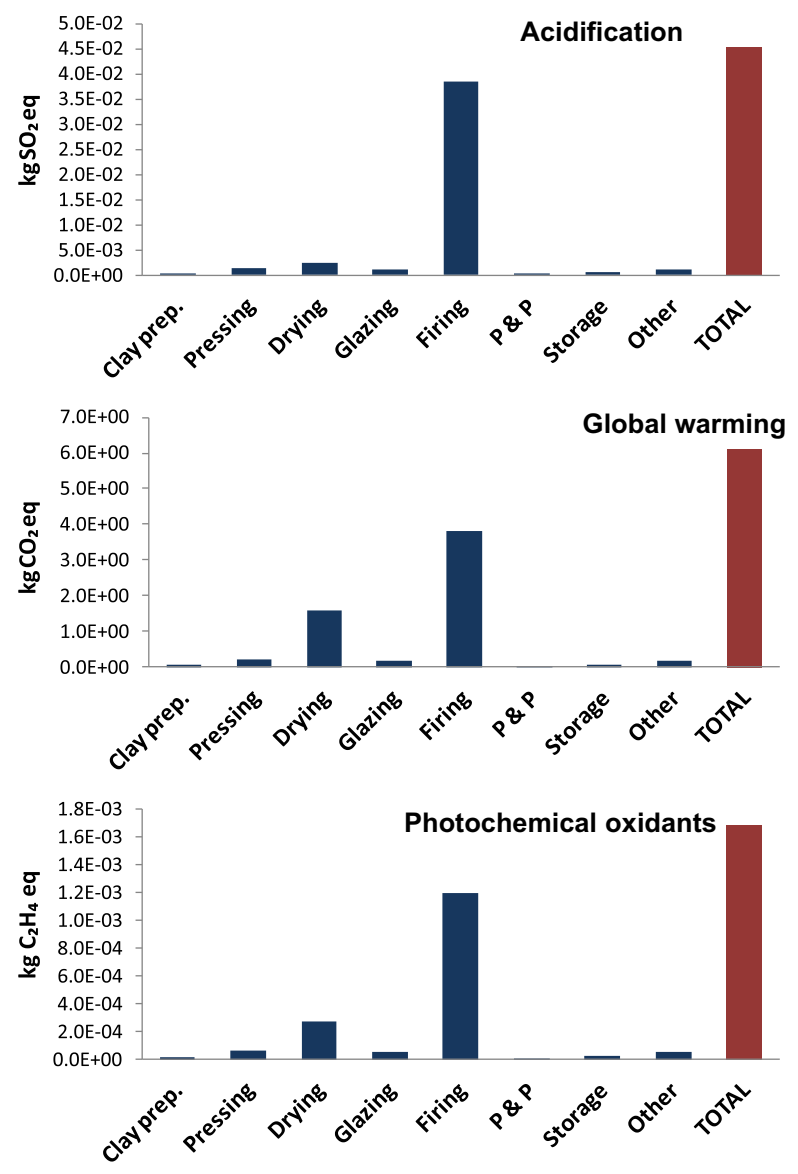

proportion to the operating time of each unit. For more detail, see Bovea et al. (2010).

It can also be observed from Table 2, that the noise levels are highest in the pressing stage. Although strictly speaking noise is not an environmental but rather a social issue, it is necessary to identify at this stage all significant impacts that should be targeted for improvements, so that an appropriate range of possible BAT options can be identified in the next stage.

Therefore, as the results suggest, BAT options should target the firing and drying stages to reduce most environmental impacts, clay preparation and pressing to reduce the emissions of particulates (and human toxicity) as well as the pressing process to reduce noise. This is discussed in the following section.

\subsection{Alternative BAT and scenarios}

As shown in Table 3, 11 BAT options have been identified from the BREF for the ceramic industry (EC, 2007) to target the hot spots in the tile manufacturing process identified in the previous step.

Fig. 4. Life cycle impacts for the baseline scenario (expressed per functional unit of $1 \mathrm{~m}^{2}$ of tiles). [P\&P - Packaging and palletising.] 
Table 3

BAT options selected for targeting the hot spots in the baseline scenario (EC, 2007).

\begin{tabular}{|c|c|c|c|c|}
\hline \multirow{3}{*}{$\frac{\text { Hot spot }}{\text { Energy efficiency }}$} & \multicolumn{2}{|c|}{ BAT option } & \multirow{3}{*}{$\begin{array}{l}\text { Type } \\
\text { Heat recovery from dirty flue gasses } \\
\text { Heat recovery from clean flue gasses }\end{array}$} & \multirow{3}{*}{$\begin{array}{l}\text { Description } \\
\text { Heat exchangers recovers heat from dirty or clean hot flu gases from the } \\
\text { kiln to preheat the combustion air which can be used either in the kiln or in } \\
\text { the dryer. }\end{array}$} \\
\hline & 1 & $1 \mathrm{a}$ & & \\
\hline & & $1 \mathrm{~b}$ & & \\
\hline \multirow[t]{3}{*}{$\begin{array}{l}\text { Particulates } \\
\text { (stack emissions) }\end{array}$} & 2 & $2 \mathrm{a}$ & $\begin{array}{l}\text { Traditional bag filters with pressure-pulse } \\
\text { regeneration }\end{array}$ & $\begin{array}{l}\text { Pulse pressure is used to clean the filter bags. Each bag will tolerate different } \\
\text { temperature depending on the type of material, e.g. synthetic bag filter tolerates }\end{array}$ \\
\hline & & $2 \mathrm{~b}$ & $\begin{array}{l}\text { High-temperature synthetic filter with } \\
\text { pressure-pulse regeneration }\end{array}$ & high temperatures. \\
\hline & 3 & & Electrostatic precipitator & Uses electrical forces to move particles from flue-gas stream to collector plates. \\
\hline \multirow{3}{*}{$\begin{array}{l}\text { Particulates } \\
\text { (diffuse emissions) }\end{array}$} & 4 & & Full enclosure of bulk storage areas & By means of the sheds or roofs to reduce diffuse dust emissions. \\
\hline & 5 & & $\begin{array}{l}\text { Dust valves with suction and bag filter in bulk } \\
\text { storage areas }\end{array}$ & Dump pits with dust suction equipment, housing and traditional bag filters. \\
\hline & 6 & & Water spraying & $\begin{array}{l}\text { Moistening of bulk storage and dusty traffic areas by using a permanent } \\
\text { water spraying installation. }\end{array}$ \\
\hline \multirow[t]{7}{*}{ Acid gases } & 7 & $7 a$ & $\begin{array}{l}\text { Cascade-type packed-bed adsorber with } \\
\mathrm{CaCO}_{3}\end{array}$ & $\begin{array}{l}\text { Flue gas is contacted with } \mathrm{CaCO}_{3} \text { or a combination of } \mathrm{CaCO}_{3} \text { and } \mathrm{Ca}(\mathrm{OH})_{2} \\
\text { in a cascade-type packed-bed reactor to remove acid gases. }\end{array}$ \\
\hline & & $7 \mathrm{~b}$ & $\begin{array}{l}\text { Cascade-type packed-bed adsorber } \\
\text { with } \mathrm{CaCO}_{3} \text { and } \mathrm{Ca}(\mathrm{OH})_{2}\end{array}$ & \\
\hline & 8 & & Module adsorber with $\mathrm{Ca}(\mathrm{OH})_{2}$ & $\begin{array}{l}\text { Adsorber with several honeycomb modules made of } \mathrm{Ca}(\mathrm{OH})_{2} \text { and located in a } \\
\text { simple steel reactor that chemically converts } \mathrm{HF} \text { in the flue gases to calcium } \\
\text { fluoride }\left(\mathrm{CaF}_{2}\right) \text { as it passes through them. }\end{array}$ \\
\hline & 9 & 9a & Dry flue gas cleaning with $\mathrm{Ca}(\mathrm{OH})_{2}$ & Particles of $\mathrm{Ca}(\mathrm{OH})_{2}$ or $\mathrm{NaHCO}_{3}$ are injected into the flue-gas stream in dry form to \\
\hline & & $9 \mathrm{~b}$ & Dry flue gas cleaning with $\mathrm{NaHCO}_{3}$ & remove acid gases from the flue gas. \\
\hline & 10 & $10 a$ & Wet flue gas cleaning with $\mathrm{Ca}(\mathrm{OH})_{2}$ or $\mathrm{CaCO}_{3}$ & A solution of $\mathrm{Ca}(\mathrm{OH})_{2}, \mathrm{CaCO}_{3}$ or $\mathrm{Na}(\mathrm{OH})_{2}$ in water pumped into the absorber \\
\hline & & $10 \mathrm{~b}$ & Wet flue gas cleaning with $\mathrm{Na}(\mathrm{OH})_{2}$ & to remove acid gases from the flue gas. \\
\hline Noise & 11 & & Sound insulation & Enclosure of the noisiest units with noise-protection walls. \\
\hline
\end{tabular}

Among these, two BAT options are aimed at improving energy efficiency, six at the abatement of particulate matter and seven at acid gas emissions $\left(\mathrm{HF}, \mathrm{HCl}, \mathrm{NO}_{x}\right.$ and $\mathrm{SO}_{x}$ ). The final BAT option is for noise reduction in the clay pressing process.

The location of different BAT within the manufacturing process is indicated in Fig. 3. Using different combinations of the BAT options, 13 alternative scenarios have been created for consideration here. These are specified in Table 4, along with the sources of environmental and cost data for different BAT and scenarios.

\subsection{Selection of sustainability indicators and sustainability} assessment

Based on the data given in the previous section, the alternative scenarios have been assessed on the environmental, economic and social sustainability using the indicators discussed in Section 2.3. These results are then used to compare the alternative scenarios with the baseline as discussed below.

\subsubsection{Environmental sustainability}

The results of the environmental sustainability assessment are shown in Fig. 5 and the impact reduction potentials relative to the baseline are given in Table 6 . As can be seen, most scenarios lead to a reduction of environmental impacts compared to the baseline. The greatest reduction potential is found for acidification $(70.3 \%$ for scenario 10$)$, photochemical oxidants ( $47.3 \%$ for scenario 10$)$ and human toxicity (51.6\% for scenario 5 ). The lowest reduction potential is for global warming and abiotic resource depletion: up to $14 \%$ for scenarios 4,5 and 10 . Therefore, it is not clear at this stage which alternatives are most sustainable - this may be easier to determine once the economic sustainability has been assessed, which is the subject of the next section.

As can also be noticed from the results, some scenarios have negative reduction potentials (Table 6 ), in effect having higher impacts than the baseline case. This is because some BAT options, such as filters or adsorption units, reduce emissions at the expense of raw materials and energy consumption as well as additional emissions along the life cycle.
Furthermore, as mentioned in the Introduction, without the use of LCA some impacts could either be missed out or underestimated. In this case, the impacts would be underestimated across all the scenarios, ranging from $28 \%$ for acidification to $35 \%$ for photochemical oxidants (see Table 5). Moreover, abiotic resource and ozone depletion would be missed out completely, as the impacts of energy consumption on the former and CFC emissions on the latter would remain unaccounted for if only direct impacts from the system were considered.

\subsubsection{Economic sustainability}

As outlined in Section 2.3.2, the economic indicators considered here are the investment and total annual costs, net annual savings and the pay-back period. To estimate these, the discount rate of 5\% (Spackman, 2008) and the plant lifetime of 20 years have been assumed. The costs used for the raw materials, utilities and energy are given in Table 7. The investment, operational and maintenance costs are as given in Table 4. The avoided costs are listed in Table 8, together with the estimated TAC and NAS.

As can be seen, the costs range widely so for the ease of comparison of the different alternatives, a scoring system has been developed as indicated in Table 9. The scores range from 1 to 5 for the investment costs and TAC, with the lowest score given to the least expensive and the highest to the most expensive alternative. The scores for NAS range from -1 where costs exceed the savings, to 5 which corresponds to the highest savings.

The scores assigned to each scenario for the different economic indicators are compared in Fig. 6. As indicated, scenarios 1, 3, 4, 5 and 13 appear to be the most profitable since they combine the least expensive investments with the highest annual savings. This is why they also have the shortest pay-back periods ( $<3$ years) and are considered to be profitable (EC, 2006a). At the other extreme, scenarios 9 and 10 have a pay-back period longer than their lifetime and hence they cannot be considered economically feasible.

As also illustrated in Fig. 6, scenarios 2, 11 and 12 have higher costs than the benefits of implementing them. As a result, they have a negative score of -1 for NAS and hence their pay-back period cannot be calculated since their investment will not be recovered. 
Table 4

Alternative scenarios considered in the study.

\begin{tabular}{|c|c|c|c|c|c|}
\hline \multicolumn{2}{|c|}{$\begin{array}{l}\text { Alternative scenarios and } \\
\text { location of BAT }\end{array}$} & \multirow{2}{*}{$\begin{array}{l}\text { Environmental benefits } \\
\nabla^{\mathrm{a}} 16.2 \% \text { of natural gas } \\
\nabla 98.5 \% \text { of PM }\end{array}$} & \multirow{2}{*}{$\begin{array}{l}\text { Other effects } \\
\Delta^{\mathrm{b}} 19 \% \text { of electricity } \\
\Delta \text { Noise }\end{array}$} & \multirow{2}{*}{$\begin{array}{l}\text { Investment }(€) \text { and O\&M costs } \\
(€ / \text { year })\end{array}$} & \multirow{2}{*}{$\begin{array}{l}\text { References } \\
\text { BAT 1a: Ganapathy (1989), TUD (2004). EC (2007), } \\
\text { Martí et al. (2010), ZareNezhad and Aminian (2010), } \\
\text { Pecomark (2011), Mezquita et al. (2012). } \\
\text { BAT 2a: Blasco et al. (1992), Ergiidenler et al. (1997), } \\
\text { Xunta de Galicia (2005), EC (2007), Mukhopadhyay } \\
\text { (2010), ITC (2010). }\end{array}$} \\
\hline 1 & $\begin{array}{l}\text { Pressing, drying, } \\
\text { glazing \& firing } \\
\text { BAT: } 1 \mathrm{a} \& 2 \mathrm{a}\end{array}$ & & & & \\
\hline 2 & $\begin{array}{l}\text { Pressing, drying, } \\
\text { glazing \& firing } \\
\text { BAT: } 1 \text { a \& } 3\end{array}$ & $\begin{array}{l}\nabla 17.2 \% \text { of natural gas } \\
\nabla 99.95 \% \text { of } \mathrm{PM}\end{array}$ & $\Delta 25.2 \%$ of electricity & $\begin{array}{l}\text { Investment: } 2,500,000-3,000,000 \\
\text { O\&M: } 300,000-400,000\end{array}$ & $\begin{array}{l}\text { BAT 1a: see above. } \\
\text { BAT 3: US EPA (2002), EC (2007). }\end{array}$ \\
\hline 3 & $\begin{array}{l}\text { Storage \& clay } \\
\text { preparation } \\
\text { BAT: } 1 \mathrm{a}, 4,5 \text { \& } 6\end{array}$ & $\begin{array}{l}\nabla 17.2 \% \text { of natural gas } \\
\nabla 99.9 \% \text { of PM }\end{array}$ & $\begin{array}{l}\Delta 8.35 \% \text { of electricity } \\
\Delta 0.12 \text { l of water } / \mathrm{m}^{2} \\
\Delta \text { Noise }\end{array}$ & $\begin{array}{l}\text { Investment: } 300,000-400,000 \\
\text { O\&M: } 50,000-150,000\end{array}$ & $\begin{array}{l}\text { BAT 1a: see above. } \\
\text { BAT 4, } 5 \text { \& 6: EC (2006), EC (2007), ITC (2010), } \\
\text { Monfort et al. (2011). }\end{array}$ \\
\hline 4 & $\begin{array}{l}\text { Drying \& firing } \\
\text { BAT: } 1 \mathrm{~b} \& 7 \mathrm{a}\end{array}$ & $\begin{array}{l}\nabla 18.1 \% \text { of natural gas } \\
\nabla 99 \% \text { of } \mathrm{PM} \\
\nabla 14 \% \text { of } \mathrm{SO}_{x} \\
\nabla 94.5 \% \text { of } \mathrm{HF} \\
\nabla 50 \% \text { of } \mathrm{HCl}\end{array}$ & $\begin{array}{l}\Delta 9.27 \% \text { of electricity } \\
\Delta 0.085 \mathrm{~kg} \mathrm{CaCO} 3 / \mathrm{m}^{2} \\
\Delta \text { Noise }\end{array}$ & $\begin{array}{l}\text { Investment: } 400,000-500.000 \\
\text { O\&M: } 100,000-200,000\end{array}$ & $\begin{array}{l}\text { BAT 1b: Ganapathy (1989), TUD (2004), EC (2007), } \\
\text { Martí (2010), ZareNezhad and Aminian (2010), } \\
\text { Pecomark (2011), Mezquita et al. (2012). } \\
\text { BAT 7a: EC (2007), ITC (2010). }\end{array}$ \\
\hline 5 & $\begin{array}{l}\text { Drying \& firing } \\
\text { BAT: } 1 \mathrm{~b} \& 7 \mathrm{~b}\end{array}$ & $\begin{array}{l}\nabla 18.5 \% \text { of natural gas } \\
\nabla 99 \% \text { of } \mathrm{PM} \\
\nabla 64 \% \text { of } \mathrm{SO}_{x} \\
\nabla 99 \% \text { of } \mathrm{HF} \\
\nabla 50 \% \text { of } \mathrm{HCl}\end{array}$ & $\begin{array}{l}\Delta 9.65 \% \text { of electricity } \\
\Delta 0.11 \mathrm{~kg} \mathrm{CaCO} / \mathrm{m}^{2} \mathrm{c} \\
\Delta \text { Noise }\end{array}$ & $\begin{array}{l}\text { Investment: } 400,000-500,000 \\
\text { O\&M: } 150,000-250,000\end{array}$ & $\begin{array}{l}\text { BAT 1b: see above } \\
\text { BAT 7b: EC (2007), ITC (2010). }\end{array}$ \\
\hline 6 & $\begin{array}{l}\text { Drying \& firing } \\
\text { BAT: } 1 \text { a } \& 8\end{array}$ & $\begin{array}{l}\nabla 17.2 \% \text { of natural gas } \\
\nabla 70 \% \text { of } \mathrm{PM} \\
\nabla 33.3 \% \text { of } \mathrm{NO}_{x} \\
\nabla 63.78 \% \text { of } \mathrm{HF}\end{array}$ & $\begin{array}{l}\Delta 6.66 \% \text { of electricity } \\
\Delta 0.43 \mathrm{~kg} \mathrm{Ca}(\mathrm{OH})_{2} / \mathrm{m}^{2}\end{array}$ & $\begin{array}{l}\text { Investment: } 700,000-800,000 \\
\text { O\&M: } 350,000-450,000\end{array}$ & $\begin{array}{l}\text { Bat 1a: see above } \\
\text { BAT 8: EC (2007), Saanilahti (2008), ITC (2010). }\end{array}$ \\
\hline 7 & $\begin{array}{l}\text { Drying \& firing } \\
\text { BAT: } 1 \mathrm{a}, 2 \mathrm{a} \& 9 \mathrm{a}\end{array}$ & $\begin{array}{l}\nabla 16.2 \% \text { of natural gas } \\
\nabla 94.5 \% \text { of } \mathrm{PM} \\
\nabla 45 \% \text { of } \mathrm{SO}_{x} \\
\nabla 93.5 \% \text { of } \mathrm{HF} \\
\nabla 47.5 \% \text { of } \mathrm{HCl}\end{array}$ & $\begin{array}{l}\Delta 17.29 \% \text { of electricity } \\
\Delta 0.073 \mathrm{~kg} \mathrm{Ca}(\mathrm{OH})_{2} / \mathrm{m}^{2} \\
\Delta \text { Noise }\end{array}$ & $\begin{array}{l}\text { Investment: } 650,000-750,000 \\
\text { O\&M: } 250,000-350,000\end{array}$ & $\begin{array}{l}\text { BAT 1a: see above } \\
\text { BAT 2a: see above. } \\
\text { BAT 9a: EC (2007), Saanilahti (2008), ITC (2010). }\end{array}$ \\
\hline 8 & $\begin{array}{l}\text { Drying \& firing } \\
\text { BAT: } 1 \mathrm{~b}, 2 \mathrm{~b} \& 9 \mathrm{a}\end{array}$ & $\begin{array}{l}\nabla 18.5 \% \text { of natural gas } \\
\nabla 99.97 \% \text { of } \mathrm{PM} \\
\nabla 45 \% \text { of } \mathrm{SO}_{x} \\
\nabla 93.5 \% \text { of } \mathrm{HF} \\
\nabla 47.5 \% \text { of } \mathrm{HCl}\end{array}$ & $\begin{array}{l}\Delta 17.29 \% \text { of electricity } \\
\Delta 0.073 \mathrm{~kg} \mathrm{Ca}(\mathrm{OH})_{2} / \mathrm{m}^{2} \\
\Delta \text { Noise }\end{array}$ & $\begin{array}{l}\text { Investment: } 650,000-750,000 \\
\text { O\&M: } 300,000-400,000\end{array}$ & $\begin{array}{l}\text { BAT 1b \& 9a: see above } \\
\text { BAT 2b: Blasco et al. (1992), Ergiidenler et al. (1997), } \\
\text { Xunta de Galicia (2005), EC (2007), } \\
\text { Mukhopadhyay (2010), ITC (2010). }\end{array}$ \\
\hline 9 & $\begin{array}{l}\text { Drying \& firing } \\
\text { BAT: } 1 \mathrm{a}, 2 \mathrm{a} \& 9 \mathrm{~b}\end{array}$ & $\begin{array}{l}\nabla 16.2 \% \text { of natural gas } \\
\nabla 99 \% \text { of } \mathrm{PM} \\
\nabla 98.5 \% \text { of } \mathrm{SO}_{x} \\
\nabla 89 \% \text { of } \mathrm{HF} \\
\nabla 95 \% \text { of } \mathrm{HCl}\end{array}$ & $\begin{array}{l}\Delta 17.29 \% \text { of electricity } \\
\Delta 0.073 \mathrm{~kg} \mathrm{NaHCO} / \mathrm{m}^{2} \\
\Delta \text { Noise }\end{array}$ & $\begin{array}{l}\text { Investment: } 650,000-750,000 \\
\text { O\&M: } 250,000-350,000\end{array}$ & $\begin{array}{l}\text { BAT 1a \& 2a: see above } \\
\text { BAT 9b: EC (2007), Saanilahti (2008), ITC (2010). }\end{array}$ \\
\hline 10 & $\begin{array}{l}\text { Drying \& firing } \\
\text { BAT: } 1 \mathrm{~b}, 2 \mathrm{~b} \& 9 \mathrm{~b}\end{array}$ & $\begin{array}{l}\nabla 19.5 \% \text { of natural gas } \\
\nabla 99.97 \% \text { of } \mathrm{PM} \\
\nabla 98.5 \% \text { of } \mathrm{SO}_{x} \\
\nabla 89 \% \text { of } \mathrm{HF} \\
\nabla 95 \% \text { of } \mathrm{HCl}\end{array}$ & $\begin{array}{l}\Delta 17.29 \% \text { of electricity } \\
\Delta 0.073 \mathrm{~kg} \mathrm{NaHCO} / \mathrm{m}^{2} \\
\Delta \text { Noise }\end{array}$ & $\begin{array}{l}\text { Investment: } 650,000-750,000 \\
\text { O\&M: } 350,000-450,000\end{array}$ & BAT 1b, 2b \& 9b: see above \\
\hline 11 & $\begin{array}{l}\text { Drying \& firing } \\
\text { BAT: } 1 \text { a \& 10a }\end{array}$ & $\begin{array}{l}\nabla 17.2 \% \text { of natural gas } \\
\nabla 100 \% \text { of } \mathrm{PM} \\
\nabla 59 \% \text { of } \mathrm{SO}_{x} \\
\nabla 72.5 \% \text { of } \mathrm{HF} \\
\nabla 99 \% \text { of } \mathrm{HCl}\end{array}$ & $\begin{array}{l}\Delta 19.09 \% \text { of electricity } \\
\Delta 0.066 \mathrm{~kg} \mathrm{Ca}(\mathrm{OH})_{2} / \mathrm{m}^{2} \\
\Delta 10.96 \mathrm{l} \text { of water } / \mathrm{m}^{2} \\
\text { High corrosion }\end{array}$ & $\begin{array}{l}\text { Investment: } 1,000,000-1,500,000 \\
\text { O\&M: } 350,000-450,000\end{array}$ & $\begin{array}{l}\text { BAT 1a: see above. } \\
\text { BAT 10a: EC (2007). }\end{array}$ \\
\hline 12 & $\begin{array}{l}\text { Drying \& firing } \\
\text { BAT: } 1 \mathrm{a} \& 10 \mathrm{~b}\end{array}$ & $\begin{array}{l}\nabla 17.2 \% \text { of natural gas } \\
\nabla 100 \% \text { of } \mathrm{PM} \\
\nabla 94 \% \text { of } \mathrm{SO}_{x} \\
\nabla 94 \% \text { of } \mathrm{HF} \\
\nabla 98 \% \text { of } \mathrm{HCl}\end{array}$ & $\begin{array}{l}\Delta 19.09 \% \text { of electricity } \\
\Delta 0.066 \mathrm{~kg} \mathrm{Na}(\mathrm{OH})_{2} / \mathrm{m}^{2} \\
\Delta 10.96 \text { l of water } / \mathrm{m}^{2} \\
\text { High corrosion }\end{array}$ & $\begin{array}{l}\text { Investment: } 1,000,000-1,500,000 \\
\text { O\&M: } 350,000-450,000\end{array}$ & $\begin{array}{l}\text { BAT 1a: see above. } \\
\text { BAT 10b: EC (2007). }\end{array}$ \\
\hline 13 & $\begin{array}{l}\text { Pressing } \\
\text { BAT: } 1 \text { a \& } 11\end{array}$ & $\begin{array}{l}\nabla 17.2 \% \text { of natural gas } \\
\nabla \text { Noise }(55 \mathrm{~dB}(\mathrm{~A}))\end{array}$ & $\Delta 6.66 \%$ of electricity & $\begin{array}{l}\text { Investment: } 100,000-200,000 \\
\text { O\&M: } 50,000-100,000\end{array}$ & $\begin{array}{l}\text { BAT 1a: see above. } \\
\text { BAT 11: EC (2007), CTE (2008), Bedmar (2011) }\end{array}$ \\
\hline
\end{tabular}

${ }^{\mathrm{a}} \nabla$ - denotes a decrease.

b $\Delta$ - denotes an increase.

c Mixture of $\mathrm{CaCO}_{3}$ and $\mathrm{Ca}(\mathrm{OH})_{2}$.

\subsubsection{Technical and social sustainability}

As discussed in Section 2.3.3, three technical and social indicators are considered here:

- maintenance requirements;

- noise; and

- level of knowledge about and accessibility of BAT.
The results for the maintenance requirements and noise for the different alternatives, estimated using the data from EC (2007) and the methodology discussed in Section 2.3.3, are shown in Table 10. Note that the scenarios with high maintenance requirements, such as periodic replacement of parts, continuous replacement of absorbents or adsorbents, periodic corrosion controls, manual cleaning of the surfaces, extraction or manual collection of waste, 

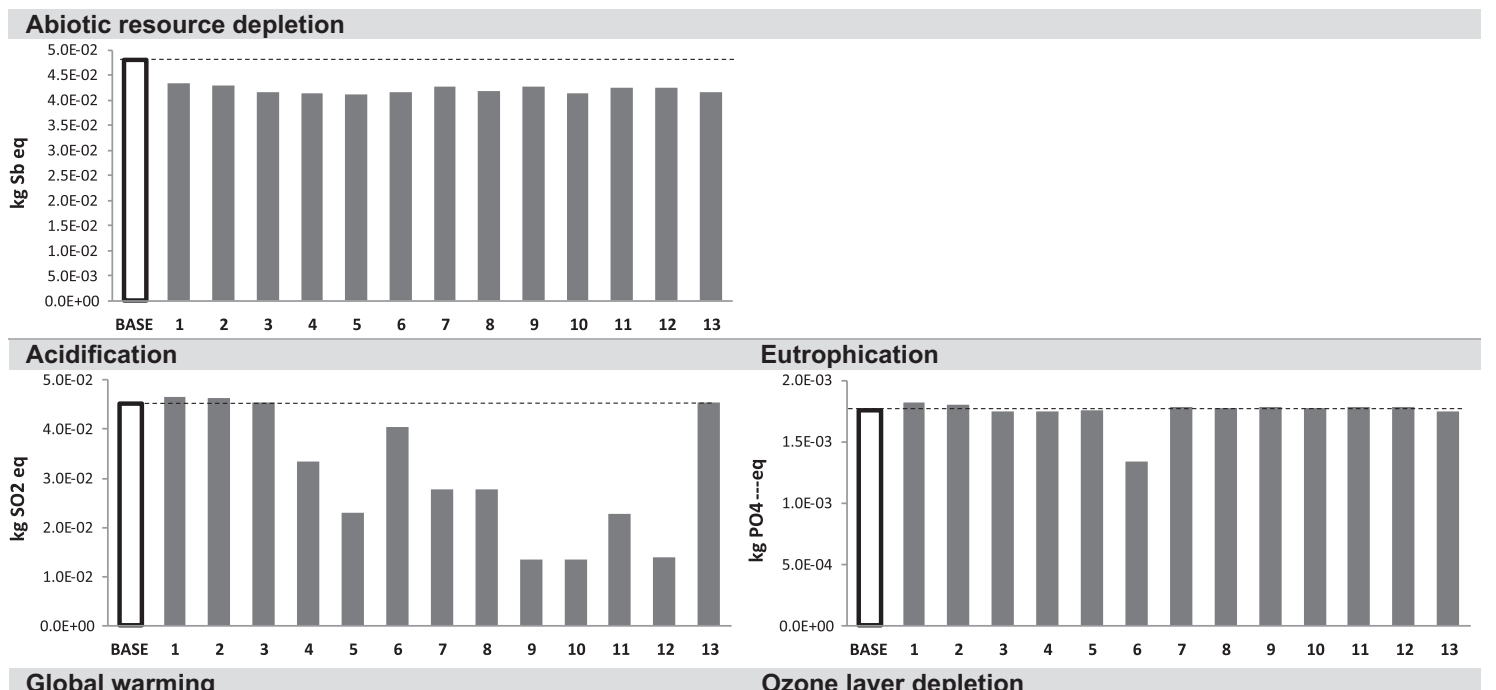

Global warming

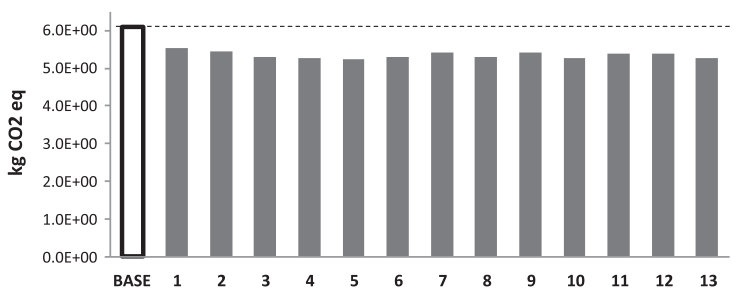

Ozone layer depletion
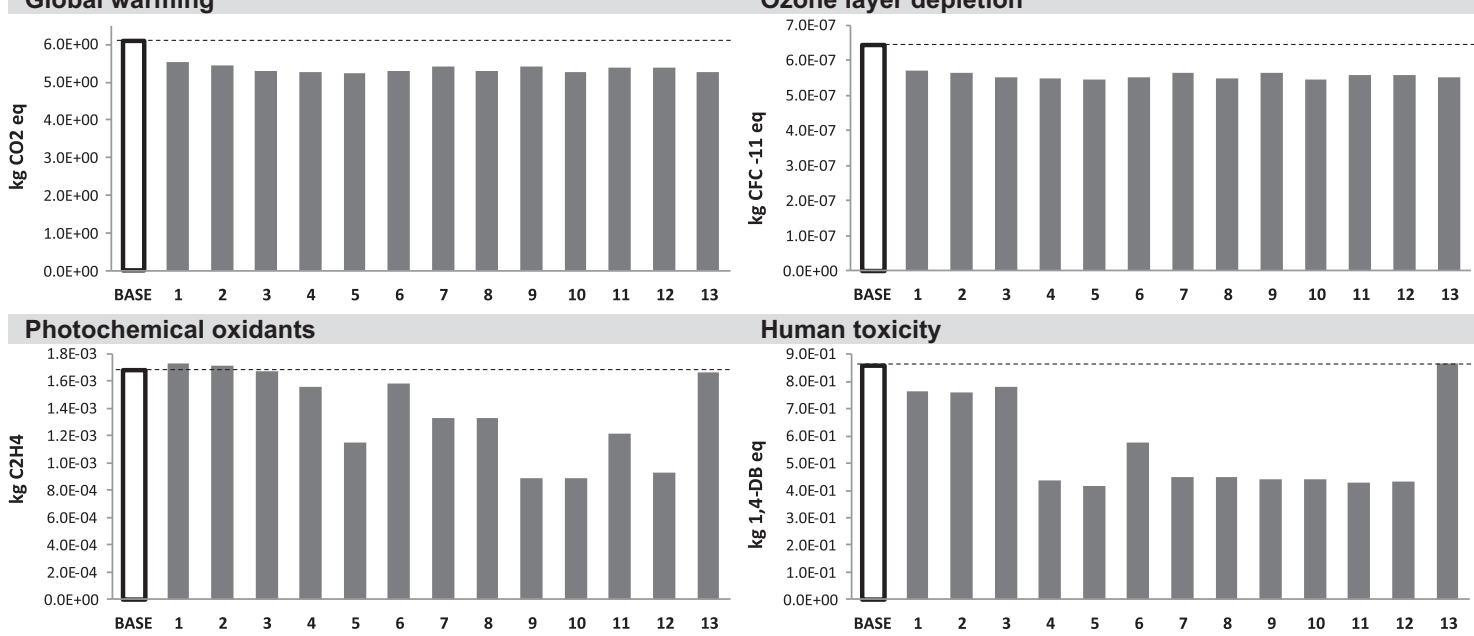

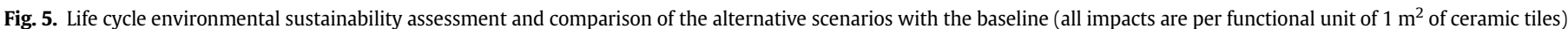

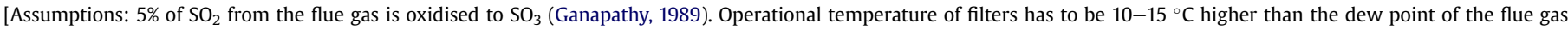

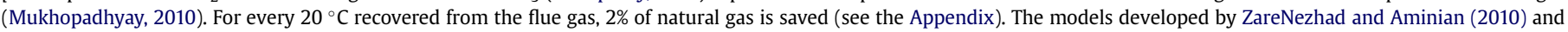

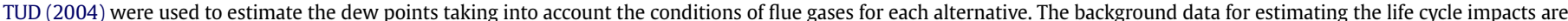
from the Ecoinvent database (Ecoinvent, 2010)].

etc. have been assigned the highest score of 4 . By contrast, scenarios where maintenance comprises only annual visual inspections have been assigned the lowest score of 1 .

For noise, the score of 1 indicates an increase on the baseline scenario, 0 no or little change $(<3 \mathrm{dBA})$ and -1 noise decrease. For the noise data for the baseline and alternative scenarios, see Table 2 and Table 4, respectively.

As can be seen from Table 10, the best options for maintenance are scenarios 3 and 13, scoring in total 1, followed by 2, 4 and 5, with the total score of 2 . Scenario 13 is the only one that reduces noise (see Table 3) whilst 2, 6, 11 and 12 maintain the same noise levels as the baseline scenario.
The data on the level of knowledge about different BAT options and their application or accessibility have been obtained by consulting three groups of stakeholders, notably:

i) sector experts (5) who prepare and manage the IPCC permit applications for ceramic tiles companies;

ii) public organisations (7) related to the ceramic industry; and

iii) tile manufacturers (8), including operators, managers and environmental experts from the companies.

In total, 20 stakeholders were surveyed, asking them to score the 11 BAT options listed in Table 3 based on the criteria and scores

Table 5

Percentage by which the impacts would be underestimated if only direct impacts were considered without applying the life cycle approach.

\begin{tabular}{|c|c|c|c|c|c|c|c|c|c|c|c|c|c|c|c|}
\hline & Baseline & 1 & 2 & 3 & 4 & 5 & 6 & 7 & 8 & 9 & 10 & 11 & 12 & 13 & Average \\
\hline Abiotic depletion & $100 \%$ & $100 \%$ & $100 \%$ & $100 \%$ & $100 \%$ & $100 \%$ & $100 \%$ & $100 \%$ & $100 \%$ & $100 \%$ & $100 \%$ & $100 \%$ & $100 \%$ & $100 \%$ & $100 \%$ \\
\hline Acidification & $14 \%$ & $17 \%$ & $16 \%$ & $15 \%$ & $20 \%$ & $30 \%$ & $17 \%$ & $26 \%$ & $26 \%$ & $54 \%$ & $54 \%$ & $32 \%$ & $53 \%$ & $15 \%$ & $28 \%$ \\
\hline Eutrophication & $30 \%$ & $32 \%$ & $32 \%$ & $30 \%$ & $30 \%$ & $30 \%$ & $39 \%$ & $31 \%$ & $31 \%$ & $31 \%$ & $31 \%$ & $31 \%$ & $31 \%$ & $29 \%$ & $31 \%$ \\
\hline Global warming & $27 \%$ & $33 \%$ & $32 \%$ & $31 \%$ & $31 \%$ & $31 \%$ & $30 \%$ & $31 \%$ & $32 \%$ & $31 \%$ & $32 \%$ & $32 \%$ & $32 \%$ & $30 \%$ & $31 \%$ \\
\hline Ozone layer depletion & $100 \%$ & $100 \%$ & $100 \%$ & $100 \%$ & $100 \%$ & $100 \%$ & $100 \%$ & $100 \%$ & $100 \%$ & $100 \%$ & $100 \%$ & $100 \%$ & $100 \%$ & $100 \%$ & $100 \%$ \\
\hline Photochemical oxidation & $27 \%$ & $29 \%$ & $28 \%$ & $27 \%$ & $29 \%$ & $39 \%$ & $28 \%$ & $35 \%$ & $35 \%$ & $53 \%$ & $52 \%$ & $39 \%$ & $51 \%$ & $26 \%$ & $35 \%$ \\
\hline Human toxicity potential & $19 \%$ & $25 \%$ & $25 \%$ & $22 \%$ & $40 \%$ & $42 \%$ & $30 \%$ & $41 \%$ & $41 \%$ & $41 \%$ & $41 \%$ & $44 \%$ & $44 \%$ & $20 \%$ & $34 \%$ \\
\hline
\end{tabular}


Table 6

Emission reduction potential of different scenarios relative to the baseline (\%).

\begin{tabular}{|c|c|c|c|c|c|c|c|}
\hline Scenario & Abiotic resource depletion & Acidification & Eutrophication & Global warming & Ozone layer depletion & Photochemical oxidation & Human toxicity \\
\hline 1 & 9.61 & -3.00 & -3.68 & 9.39 & 11.40 & -2.77 & 10.86 \\
\hline 2 & 10.92 & -2.62 & -2.98 & 10.70 & 12.61 & -2.18 & 11.49 \\
\hline 3 & 13.33 & -0.71 & 0.11 & 13.16 & 14.33 & 0.38 & 9.21 \\
\hline 4 & 14.00 & 25.99 & 0.08 & 13.82 & 15.06 & 7.20 & 49.26 \\
\hline 5 & 14.27 & 49.16 & 0.05 & 14.09 & 15.36 & 31.54 & 51.64 \\
\hline 6 & 13.55 & 10.74 & 23.78 & 13.36 & 14.44 & 5.83 & 33.09 \\
\hline 7 & 11.23 & 38.53 & -1.59 & 11.04 & 12.56 & 20.89 & 47.72 \\
\hline 8 & 13.18 & 38.57 & -1.36 & 12.97 & 14.59 & 21.12 & 47.77 \\
\hline 9 & 11.23 & 70.28 & -1.60 & 11.04 & 12.56 & 46.97 & 48.86 \\
\hline 10 & 14.02 & 70.34 & -1.26 & 13.81 & 15.47 & 47.30 & 48.88 \\
\hline 11 & 11.82 & 49.78 & -1.83 & 11.61 & 13.26 & 27.54 & 50.10 \\
\hline 12 & 11.82 & 69.31 & -1.84 & 11.61 & 13.26 & 44.60 & 49.74 \\
\hline 13 & 13.63 & -0.47 & 0.50 & 13.46 & 14.56 & 0.71 & -0.78 \\
\hline
\end{tabular}

Table 7

Average prices of raw materials, utilities and energy.

\begin{tabular}{|c|c|c|c|c|c|}
\hline & Cost & Unit & & Cost & Unit \\
\hline Natural gas ${ }^{\mathrm{a}}$ & 0.32 & $€ / \mathrm{m}^{3}$ & Calcium carbonate $\left(\mathrm{CaCO}_{3}\right)$ with calcium hydroxide $\left(\mathrm{Ca}(\mathrm{OH})_{2}\right)^{\mathrm{c}}$ & 99 & $€ / \mathrm{t}$ \\
\hline Electricity $^{\mathrm{a}}$ & 0.15 & $€ / \mathrm{kWh}$ & Calcium hydroxide $\left(\mathrm{Ca}(\mathrm{OH})_{2}\right)^{d}$ & $100-130^{\mathrm{e}}$ & $€ / \mathrm{t}$ \\
\hline Water ${ }^{\mathrm{b}}$ & 1.53 & $€ / \mathrm{m}^{3}$ & Sodium bicarbonate $\left(\mathrm{NaHCO}_{3}\right)^{\mathrm{d}}$ & 220 & $€ / \mathrm{t}$ \\
\hline Calcium carbonate $\left(\mathrm{CaCO}_{3}\right)^{\mathrm{c}}$ & 59.00 & $€ / \mathrm{t}$ & Caustic soda $\left(\mathrm{Na}(\mathrm{OH})_{2}\right)^{\mathrm{c}}$ & 102.5 & $€ / \mathrm{t}$ \\
\hline
\end{tabular}

a Department of industry, energy and tourism (2012).

b Primary data collected in this study from industry.

c EC (2007).

d Saanilahti (2008).

e Costs range depending on the density.

given in Table 1. The results of the survey displayed in Fig. 7 indicate that the greatest level of knowledge across the three groups of stakeholders is related to BAT options $4,5,6$ and 11, scoring between 3.8 and 3.9 out of 4 . These are related to the traditional techniques for removal of particulates and sound proofing (see Table 3). By contrast, the least well-known techniques are BAT 8 , $10 \mathrm{a} \& 10 \mathrm{~b}$ and $2 \mathrm{~b}$, scoring $1.3,2.1$ and 2.2, respectively. These are mostly related to acid gas removal and high-temperature filters for particulates. Perhaps unsurprisingly, the tile manufacturers had overall the highest level of knowledge about different BAT options compared to the other two expert groups.

Applying these results to each scenario, using the methodology outlined in Section 2.3.3, yields the results in Fig. 8. Overall, scenarios 1, 3 and 13 are the best for both criteria since they represent a combination of high-scoring individual BAT, including 2a, 4, 5, 6 and 11 (see Table 4).

Table 8

Summary of costs and net annual savings for different scenarios. ${ }^{a}$

\begin{tabular}{lllc}
\hline Scenario & $\begin{array}{l}\text { Total annual } \\
\text { costs }(€ / \mathrm{yr})\end{array}$ & $\begin{array}{l}\text { Avoided } \\
\text { costs }(€ / \mathrm{yr})\end{array}$ & $\begin{array}{l}\text { Net annual } \\
\text { savings }(€ / \mathrm{yr})\end{array}$ \\
\hline 1 & 318,000 & 460,000 & 142,000 \\
2 & 620,000 & 488,000 & $-132,000$ \\
3 & 157,000 & 488,000 & 331,000 \\
4 & 212,000 & 514,000 & 302,000 \\
5 & 246,000 & 525,000 & 279,000 \\
6 & 443,000 & 488,000 & 45,000 \\
7 & 378,000 & 460,000 & 82,000 \\
8 & 474,000 & 525,000 & 51,000 \\
9 & 419,000 & 460,000 & 41,000 \\
10 & 515,000 & 554,000 & 39,000 \\
11 & 548,000 & 488,000 & $-60,000$ \\
12 & 553,000 & 488,000 & $-65,000$ \\
13 & 119,000 & 488,000 & 369,000 \\
\hline
\end{tabular}

\footnotetext{
${ }^{\mathrm{a}}$ For investment costs, see Table 4.
}

\subsection{Selection of most sustainable BAT and scenarios}

Based on the above sustainability assessment, the next step involves identification and selection of the most sustainable scenario(s). As outlined in Section 2.4, to aid the selection process, an initial screening is carried out by comparing the scenarios on their environmental and economic performance or eco-efficiency. This is discussed next.

\subsubsection{Initial screening: eco-efficiency analysis}

The eco-efficiency analysis given in Fig. 9 compares the environmental impact reduction potentials and the net annual savings for each scenario. As shown, scenarios 1, 3, 4, 5, 7, 8 and 13 are the only ones which appear in the maximum eco-efficiency area (upper right-hand square in the figure) for at least one category. As a result, only these scenarios are considered eco-efficient and hence can

Table 9

Scoring criteria for the economic indicators.

\begin{tabular}{llc}
\hline Economic indicators & Range & Score \\
\hline Investment cost $(€)$ & $<350,000$ & 1 \\
& $350,000-700,000$ & 2 \\
& $700,000-1,050,000$ & 3 \\
& $1,050,000-1,400,000$ & 4 \\
Total annual cost $(€ /$ year $)$ & $>1,400,000$ & 5 \\
& $<200,000$ & 1 \\
& $200,000-300,000$ & 2 \\
Net annual savings $(€ /$ year $)$ & $300,000-400,000$ & 3 \\
& $400,000-500,000$ & 4 \\
& $>500,000$ & 5 \\
& $<0$ & -1 \\
& $0-50,000$ & 1 \\
& $50,000-100,000$ & 2 \\
& $100,000-200,000$ & 3 \\
& $200,000-300,000$ & 4 \\
& $>300,000$ & 5 \\
\hline
\end{tabular}




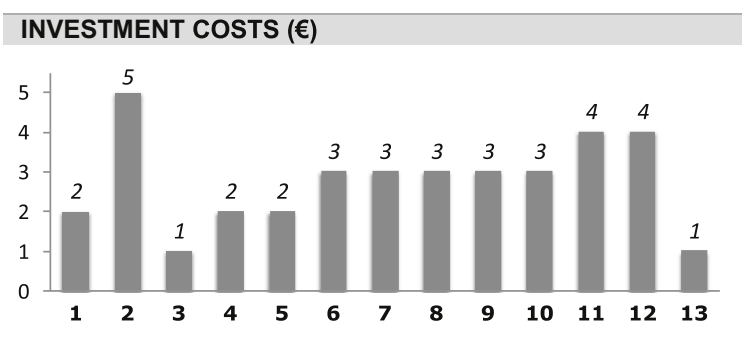

\section{TOTAL ANNUAL COSTS (€/yr)}

NET ANNUAL SAVINGS ( $€ /$ yr)
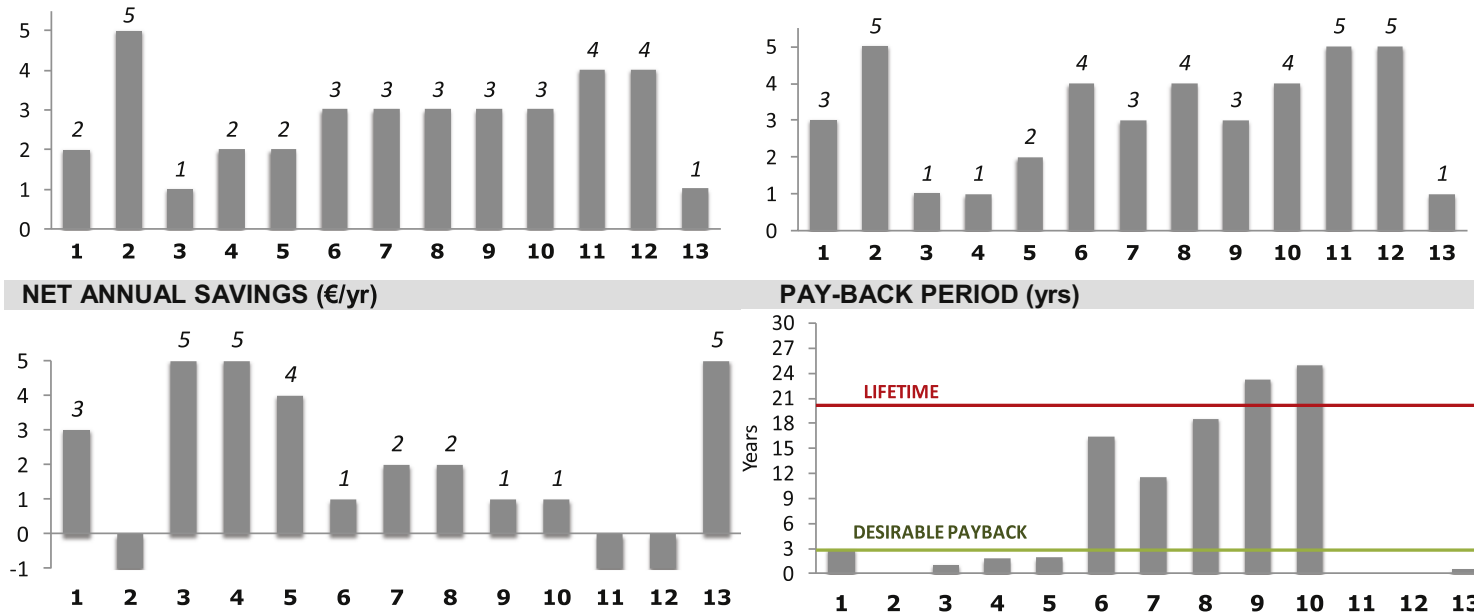

PAY-BACK PERIOD (yrs)

Fig. 6. Economic sustainability assessment based on the scoring method given in Table 9 .

Table 10

Total scores for maintenance requirements and noise for different scenarios.

\begin{tabular}{lrlllllllllllr}
\hline Scenarios & 1 & 2 & 3 & 4 & 5 & 6 & 7 & 8 & 9 & 10 & 11 & 12 & 13 \\
\hline Maintenance & 3 & 2 & 1 & 2 & 2 & 3 & 3 & 3 & 3 & 3 & 4 & 4 & 1 \\
Noise & 1 & 0 & 1 & 1 & 1 & 0 & 1 & 1 & 1 & 1 & 0 & 0 & -1 \\
\hline
\end{tabular}

pass to the next stage of sustainability assessment. It is also interesting to observe that the most expensive scenario does not necessarily lead to the best environmental performance. This is the case for scenario 2, which has both the lowest net savings and environmental improvements of all the scenarios considered.

\subsubsection{Sustainability analysis}

Applying the normalisation process outlined in Section 2.4.2 to the eco-efficient alternatives identified above gives the 'sustainability footprint' in Fig. 10. As shown, scenario 5 is the best option for all environmental indicators apart from eutrophication for which scenario 13 is best. On the other hand, scenario 13 has high photochemical oxidants and human toxicity potentials. Options 3 and 13 are best economically as well as for the maintenance and level of knowledge/accessibility of their BAT options. Scenario 13 is also best for the noise levels.

Therefore, if all the criteria are considered to be equally important, it could be argued that of the scenarios considered in this work, 5 and 13 represent the most sustainable BAT for the

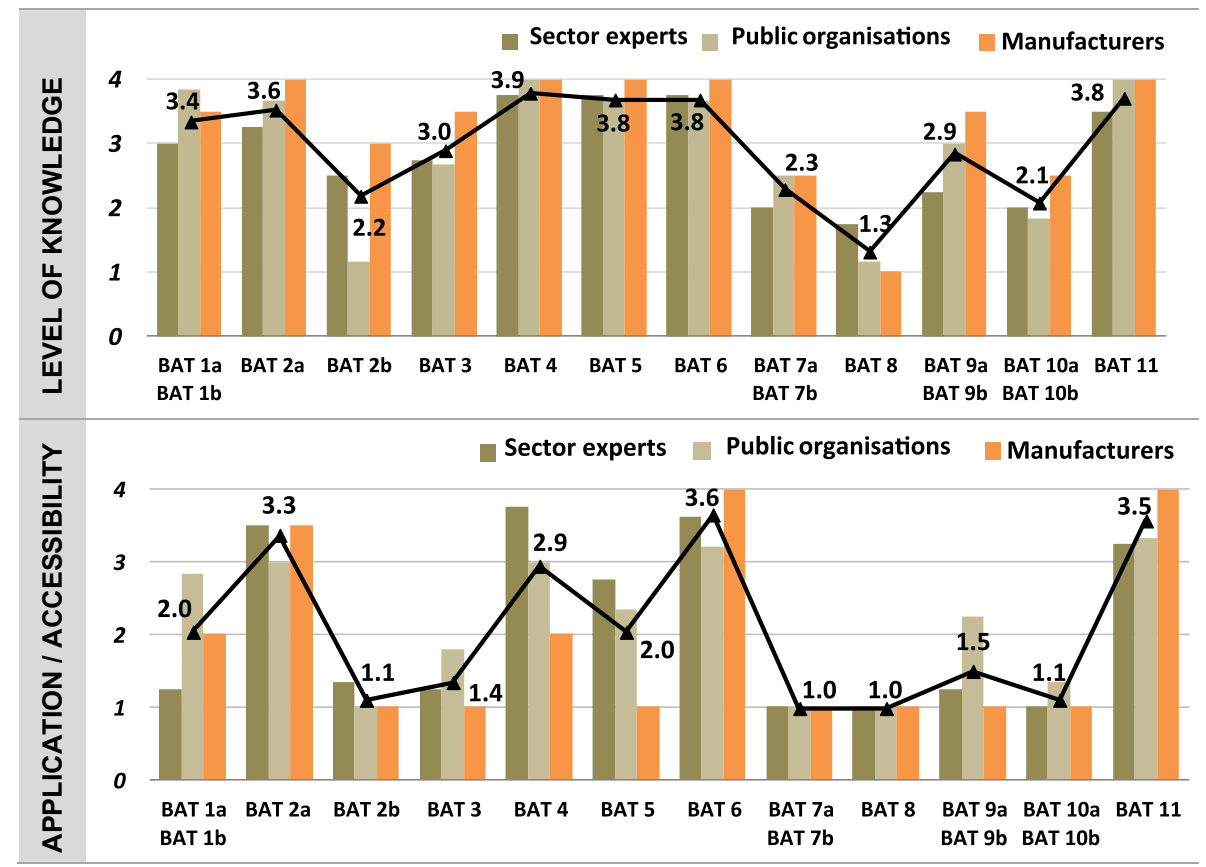

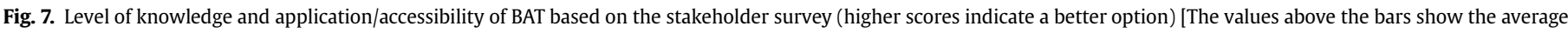
score for the three stakeholder groups.]. 

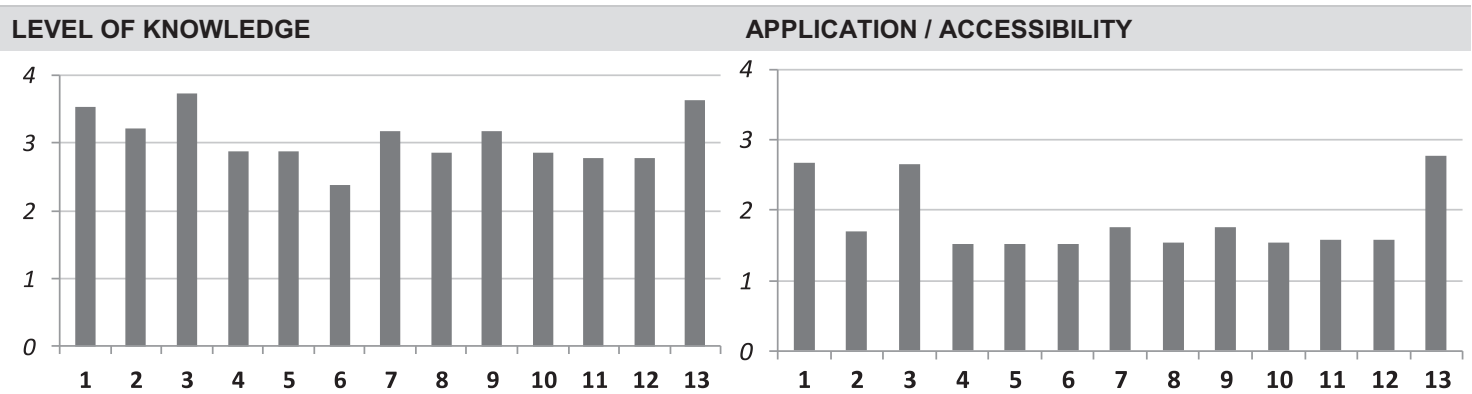

Fig. 8. The scores for the level of knowledge and application of BAT for different scenarios (higher scores indicates a better option).
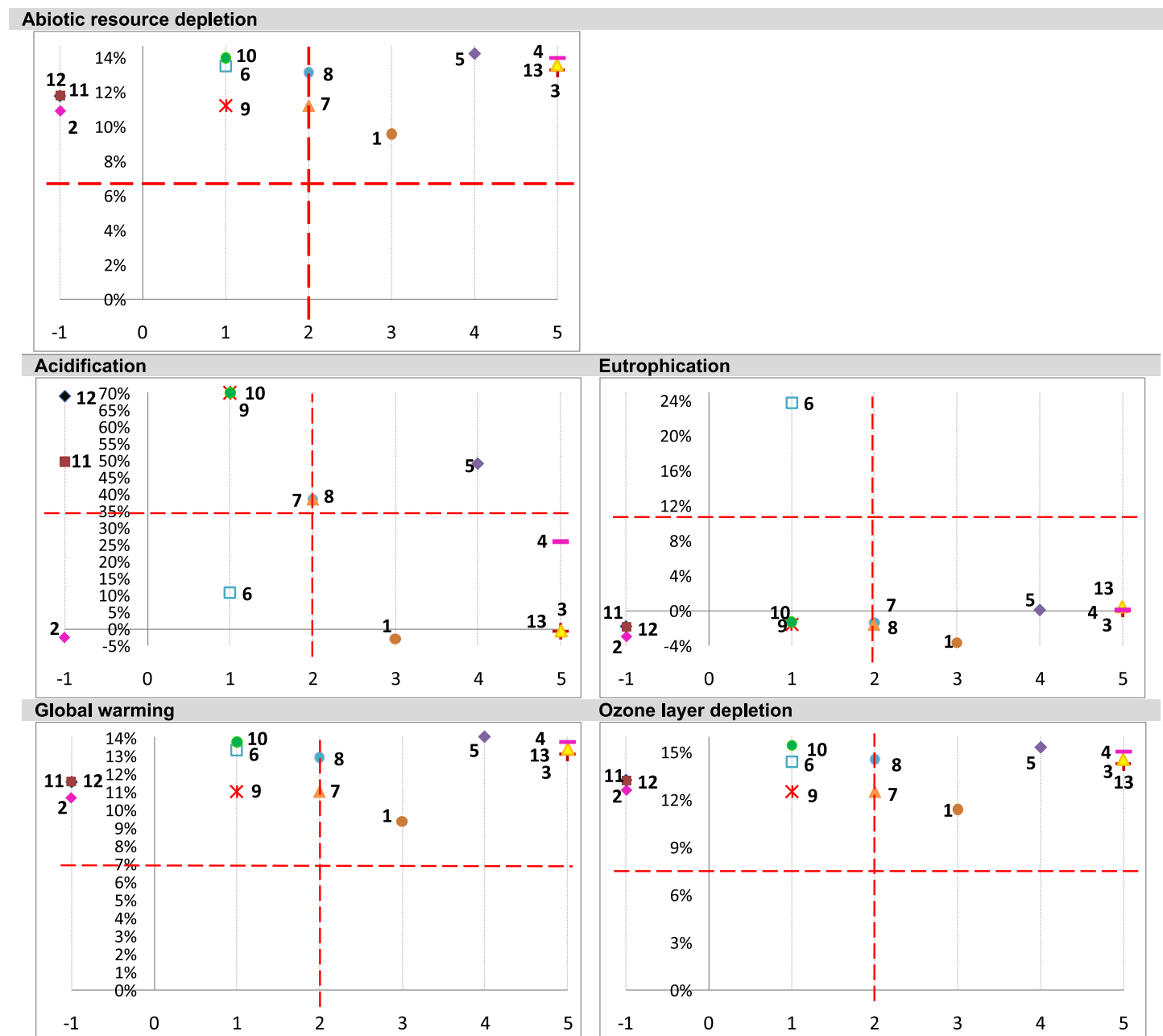

Ozone layer depletio

Photochemical oxidants
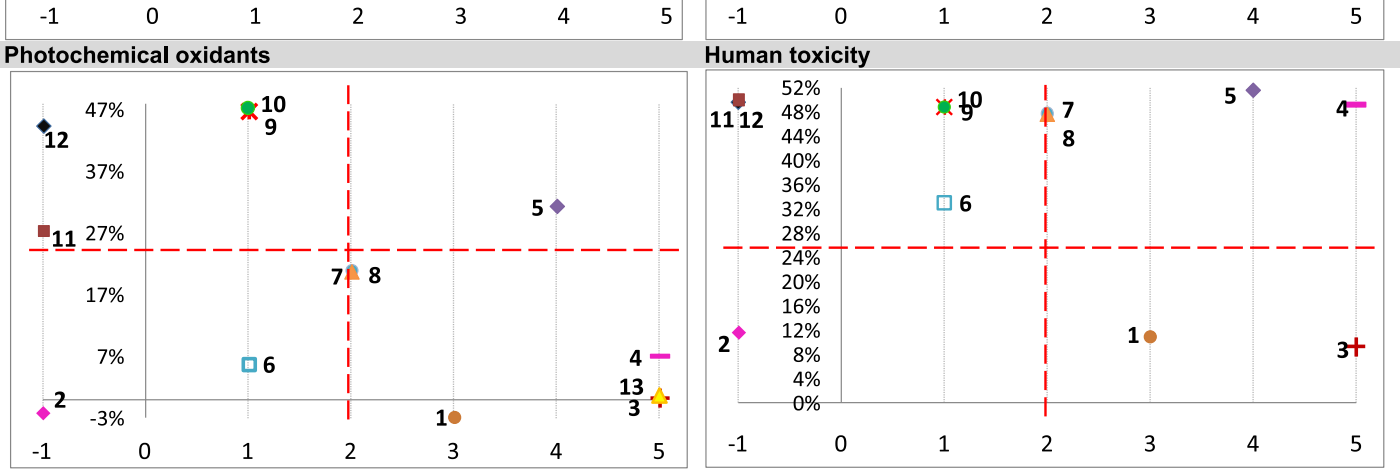

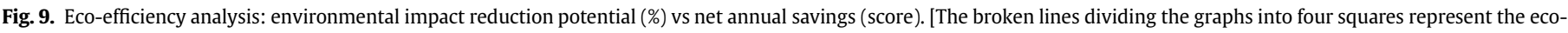
efficiency lines as defined in Fig. 2 and Section 2.4.1. The options in the top right-hand corner are considered eco-efficient.]. 

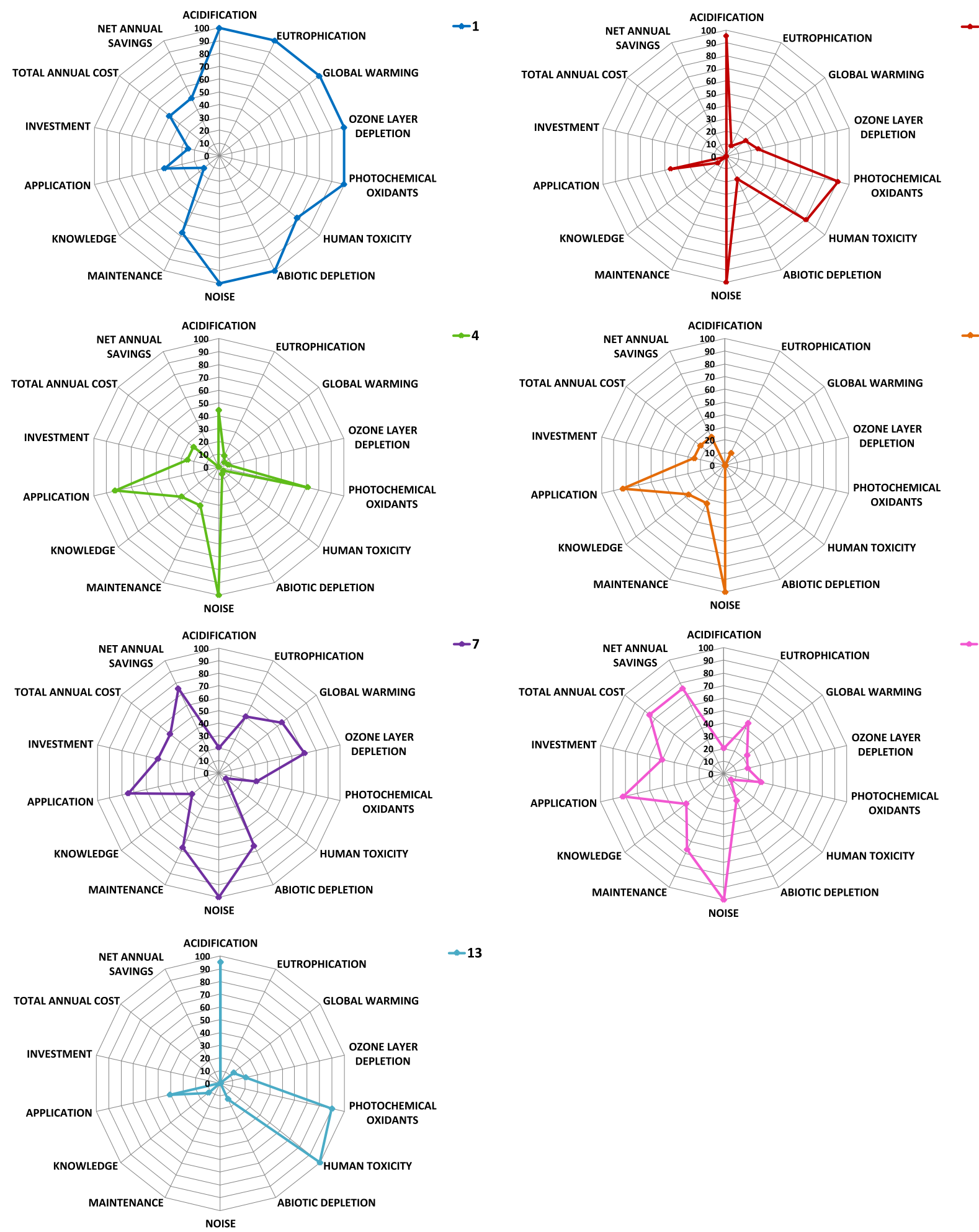

$\sim 13$

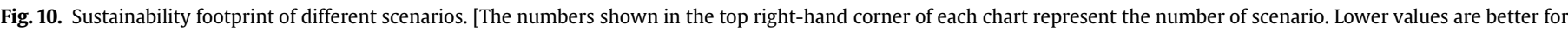
all indicators so that the smaller area bounded by the connecting lines on the diagram indicates a better scenario.].

ceramic manufacturing industry. However, if some criteria are considered to be more important than the others, then the choice of the best alternative(s) could change. This can only be determined in a real decision-making context, based on decision-makers' preferences. Consideration of these is outside the scope of this paper and is therefore not considered here.

\section{Conclusions}

This paper has proposed a methodology for identifying most appropriate and sustainable BAT options by considering a range of environmental, economic and social requirements specified in the Industrial Emissions Directive and the BREFs. It has also shown how 
LCA can be integrated within such a methodology to ensure that the environment is protected as a 'whole' as required by the Directive to prevent shifting the environmental burdens upstream or downstream of the industrial installation considered. The methodology involves identification of the environmental hot spots in the manufacturing process using LCA, which then guides the selection of candidate BAT options targeting the hot spots. The BAT options are then assessed on sustainability using relevant environmental, economic, technical and social indicators. This enables benchmarking of different options and selection of the most appropriate alternative(s) for the system of interest.

The application of the methodology has been illustrated by a case study of ceramic tiles produced in Spain with the aim of providing a practical guidance for improving the sustainability of the manufacturing process through the selection of most appropriate BAT for this sector. The results indicate that firing and drying are the hot spots for most environmental impacts considered due to high energy requirements and emissions of acid gases. Furthermore, clay preparation and pressing represent hot spots for the emissions of particulates; clay pressing also generates high noise levels. To target these, 11 BAT options used in 13 alternative configurations in the manufacturing process have been considered and assessed on sustainability. Applying the methodology developed in this work, it has been found that of the options considered here the most sustainable BAT for the ceramic tiles industry include heat recovery from flue gas and its clean-up of with $\mathrm{CaCO}_{3}$ and/or $\mathrm{Ca}(\mathrm{OH})_{2}$. Depending on the scenario, cost savings of up to $30 \%$ can be achieved with these BAT options and up to $97 \%$ reduction in some of the life cycle environmental impacts. However, it should be noted that these results are based on the assumption that all the sustainability indicators are of equal importance - the outcomes of the sustainability assessment could change depending on the preferences that decision-makers would have for different sustainability aspects.

\section{Acknowledgements}

The authors gratefully acknowledge the funding from the Spanish Ministry of Science and Innovation, the Generalitat Valenciana, tile manufacturers and other stakeholders for their invaluable help with this research.

\section{Appendix A. Calculation of energy savings by heat recovery from flue gases}

It has been assumed here that for every $20{ }^{\circ} \mathrm{C}$ recovered from the flue gas, $2 \%$ of natural gas is saved. The calculations for this are shown below.

The amount of heat that can be recovered from flue gases can be calculated as follows:

$\bar{Q}=\bar{m} \times C p \times\left(T_{\mathrm{O}}-T_{\mathrm{I}}\right) \quad(\mathrm{kJ} / \mathrm{s})$

where:

$$
\begin{aligned}
& \bar{m}-\text { mass flow of flue gas }(\mathrm{kg} / \mathrm{s}) \\
& C p-\text { heat capacity of flue gas }\left(\mathrm{kJ} / \mathrm{kg}{ }^{\circ} \mathrm{C}\right) \\
& T_{\mathrm{O}}-\text { outlet temperature of flue gas } \\
& T_{\mathrm{I}}-\text { inlet temperature of flue gas }
\end{aligned}
$$

The volume of hot flue gasses from the kilns is $69,000 \mathrm{Nm}^{3} / \mathrm{h}$ (Table 2) with a density of $0.5895 \mathrm{~kg} / \mathrm{Nm}^{3}$ and a heat capacity of $1.195 \mathrm{~kJ} / \mathrm{kg}{ }^{\circ} \mathrm{C}$ (Villaflor et al., 2008). Assuming the temperature difference between the inlet and outlet temperatures of the flue gas of $20^{\circ} \mathrm{C}$ and using the above equation, the heat that could be recovered from the hot gases is equivalent to $270 \mathrm{~kJ} / \mathrm{s}$ for every $20^{\circ} \mathrm{C}$.
For the average production of tiles of $11,000 \mathrm{~kg} / \mathrm{h}$ (the average for the 20 manufacturing sites considered), the dryers and kilns consume 1400 and $3000 \mathrm{~kJ} / \mathrm{kg}$ of natural gas, respectively (EC, 2007) or around $13,450 \mathrm{~kJ} / \mathrm{s}$ in total. Therefore, the estimated amount of heat of $270 \mathrm{~kJ} / \mathrm{s}$ that can be recovered from the hot flue gasses for every $20^{\circ} \mathrm{C}$ represents $2 \%$ of the total natural gas demand in the tiles manufacturing process.

\section{References}

Afgan, N.H., Carvalho, M.G., 2002. Multi-criteria assessment of new and renewable energy power plants. Energy 27, 739-755.

Azapagic, A., Perdan, S., 2005a. An integrated sustainability decision-support framework: problem structuring, part I. International Journal of Sustainable Development \& World Ecology 12 (2), 98-111.

Azapagic, A., Perdan, S., 2005b. An integrated sustainability decision-support framework: methods and tools for problem analysis, Part II. International Journal of Sustainable Development \& World Ecology 12 (2), 112-131.

Bedmar, 2011. Price List 2010-2011. Commercial Catalog, Barcelona, Spain.

Blasco, A., Escardino, A., Busani, G., Montort, E., Amorós, J.L., Enrique, J., Beltrán, V., Negre, P., 1992. Tratamiento de emisiones gaseosas, efluentes líquidos y residuos sólidos de la Industria Cerámica, first ed. Instituto de Tecnología CerámicaAsociación de Investigación de las Industrias Cerámicas (ITC-AICE), Castellón, Spain (in Spanish).

Bovea, M.D., Díaz-Albo, E., Gallardo, A., Colomer, F.J., Serrano, J., 2010. Environmental performance of ceramic tiles: improvement proposals. Materials and Design 31, 35-41.

Código Técnico de la Edificación (CTE), 2008. Ministerio de la Vivienda, Spain (in Spanish).

Department of industry, energy and tourism, 2012. Energy Taxes. Spanish Government, Spain. www.minetur.gob.es/energia/electricidad/Tarifas/Tarifas2008/ Paginas/precios.aspx.

Derden, A., Vercaemst, P., Dijkmans, R., 2002. Best available techniques (BAT) for the fruit and vegetable processing industry. Resources, Conservation and Recycling 34, 261-271.

Doukas, H., Patlitzianas, K.D., Psarras, J., 2006. Supporting sustainable electricity technologies in Greece using MCDM. Resources Policy 31, 129-136.

EC, 2006a. IPPC Reference Document on Economics and Cross-Media Effects. European Commission, DG JRC, Sevilla, Spain. http://eippcb.jrc.es/reference/ BREF/ecm_bref_0706.pdf.

EC, 2006b. IPPC Reference Document on Best Available Techniques (BAT) on Emissions from Storage. European Commission, DG JRC, Sevilla, Spain. http:// eippcb.jrc.es/reference/BREF/esb_bref_0706.pdf.

EC, 2007. IPCC Reference Document on Best Available Techniques (BAT) in the Ceramic Manufacturing Industry. European Commission, Institute for Prospective Technological Studies, Sevilla, Spain. http://eippcb.jrc.es/reference/ BREF/cer_bref_0807.pdf.

EC, 2010. Directive 2010/75/EU of the European Parliament and the Council of 24 November on industrial emissions. Official Journal of the European Union L 334/ 17. 17.12.2010.

Ecoinvent, 2010. Ecoinvent V2.1 Database. Swiss Centre For Life Cycle Inventories Dübendorf, Switzerland. www.ecoinvent.org.

Ergiidenler, A., Tan, W., Brereton, C.M.H., Lim, C.J., Grace, J.R., Gennrich, T.J., 1997. Performance of high-temperature fabric filters under gasification and combustion conditions. Separation and Purification Technology 11, 1-16.

Ganapathy, V., 1989. Cold end corrosion: causes and cures. Hydrocarbon Processing 68 (1), 57-59.

García, N., Caballero, J.A., 2011. Economic and environmental assessment of alternatives to the extraction of acetic acid from water. Industrial \& Engineering Chemistry Research 50, 10717-10729.

Geldermann, J., Rentz, O., 2001. Integrated technique assessment with imprecise information as a support for the determination of best available techniques (BAT). OR Spectrum 23 (1), 137-157.

Georgopoulou, E., Hontou, V., Gakis, N., Sarafidis, Y., Mirasgedis, S., Lalas, D.P., Loukatos, A., GArgoulas, N., Mentzis, A., Economidis, D., Triantafilopoulos, T., Korizi, K., 2008. BEAsT: a decision-support tool for assessing the environmental benefits and the economic attractiveness of best available techniques in industry. Journal of Cleaner Production 16, 359-373.

Giner-Santonja, G., Aragonés-Beltrán, P., Niclós-Ferragut, J., 2012. The application of the analytic network process to the assessment of best available techniques. Journal of Cleaner Production 25, 86-95.

Gómez-López, M.D., Bayo, J., García-Cascales, M.S., Angosto, J.M., 2009. Decision support in disinfection technologies for treated wastewater reuse. Journal of Cleaner Production 17, 1504-1511.

Guinée, J.B., 2002. Handbook on Life Cycle Assessment: Operational Guide to the ISO Standards. Kluwer Academic Publisher, Dordrecht, The Netherlands.

Guo, H.C., Chen, B., Yu, X.L., Huang, G.H., Liu, L., Nie, X.H., 2006. Assessment of cleaner production options for alcohol industry of China: a study in the Shouguang Alcohol Factory. Journal of Cleaner Production 14 (1), 94-103.

Ibáñez-Forés, V., Bovea, M.D., Simó, A., 2011. Life cycle assessment of ceramic tiles. Environmental and statistical analysis. International Journal of Life Cycle Assessment 16, 916-928. 
Instituto de Tecnología Cerámica (ITC), 2010. BAT Guidelines for the Manufacturing Sector of Ceramic Tiles in Valencia Region (In Spanish). Centro de Tecnologías Limpias, Conselleria de Medi Ambient, Aigua, Urbanisme i Habitatge, Generalitat Valenciana, Valencia, Spain. Available at: http://www.cma.gva.es/ctl.

ISO, 2006. ISO/TR 14025: Environmental Labels and Declarations - Type III Environmental Declarations - Principles and Procedures. ISO, Geneva.

Karavanas, A., Chaloulakou, A., Spyrellis, N., 2009. Evaluation of the implementation of best available techniques in IPPC context: an environmental performance indicators approach. Journal of Cleaner Production 17, 480-486.

Kocaoglu, D., Williamson, K., Saberiyan, A., Olive, L., 2001. Technology selection in Brownfields redevelopment. In: Proceedings of the Portland International Conference on Management of Engineering and Technology (PICMET), Portland, U.S.A.

Lin, G.T.R., Shen, Y.C., 2010. A collaborative model for technology evaluation and decisión-making. Journal of Scientific \& Industrial Research 69, 94-100.

Liu, X., Wen, Z., 2012. Best available techniques and pollution control: a case study on China's thermal power industry. Journal of Cleaner Production 23, 113-121.

Martí, J.R., Sánchez, A., Vaquer, F.A., Sebastiá, R., 2010. Recuperador de energía para el proceso de ahorro energético en el sistema de produción de baldosas, ladrilos $\mathrm{y}$ tejas cerámicas (in Spanish). In: Proceedings of the XI Global Forum on Ceramic Tile (QUALICER'10), Castellón, Spain.

Mavrotas, G., Georgopoulou, E., Mirasgedis, S., Sarafidis, Y., Lalas, D., Hontou, V., Gakis, N., 2007. An integrated approach for the selection of Best Available Techniques (BAT) for the industries in the greater Athens area using multiobjective combinatorial optimization. Energy Economics 29, 953-973.

Mezquita, A., Monfort, E., Vaquer, E., Ferrer, S., Arnal, M.A., Toledo, J., Cuesta, M.A., 2012. Optimización energética en la fabricación de baldosas cerámicas mediante el uso de aceite térmico (in Spanish). In: Proceedings of the XII Global Forum on Ceramic Tile (QUALICER'12), Castellón, Spain.

Monfort, E., Sanfelix, V., Celades, I., Gomar, S., Martín, F., Aceña, B., Pascual, A., 2011. Diffuse PM10 emission factors associated with dust abatement technologies in the ceramic industry. Atmospheric Environment 45 (39), 7286-7292.

Mukhopadhyay, A., 2010. Pulse-jet filtration: an effective way to control industria pollution part II: process characterization and evaluation of filter media. Textile Progress 42 (1), 1-97.

Nicholas, M.J., Clift, R., Walker, F.C., Azapagic, A., Porter, D.E., 2000. Determination of 'Best available techniques' for integrated pollution prevention and control: a life cycle approach. Process Safety and Environmental Protection (PSEP) 78 (3), 193-203.
Pecomark, 2011. Price List 2011-2012. Commercial Catalog, Barcelona, Spain

Pilavachi, P.A., Roumpeas, C.P., Minett, S., Afgan, N.H., 2006. Multi-criteria evaluation for CHP system options. Energy Conversion and Management 47, 3519-3529.

Pilavachi, P.A., Stephanidis, S.D., Pappas, V.A., Afgan, N.H., 2009. Multi-criteria evaluation of hydrogen and natural gas fuelled power plant technologies. Applied Thermal Engineering 29, 2228-2234.

PRé Consultants, 2011. SIMAPRO V7.3.2. PRé Consultants, B.V. Amersfoort, The Netherlands.

Saanilahti, S., 2008. Reducing $\mathrm{HCl}$ and $\mathrm{SO}_{2}$ Emissions with Dry Flue Gas Cleaning Process. Final thesis, Tampere Polytechnic - University of Applied Sciences, Tampere, Finland.

Sadiq, R., Khan, F.I., Veitch, B., 2005. Evaluating offshore technologies for produced water management using GreenPro-I - a risk-based life cycle analysis for green and clean process selection and design. Computers and Chemical Engineering 29 (5), 1023-1039.

Schollenberger, H., Treitz, M., Geldermann, J., 2008. Adapting the European approach of best available techniques: case studies from Chile and China. Journal of Cleaner Production 16 (17), 1856-1864

Shehabuddeen, N., Probert, D., Phaal, R., 2006. From theory to practice: challenges in operationalising a technology selection framework. Technovation 26 (3) $324-335$.

Spackman, M., 2008. Time preference, the cost of capital and PPPs. In: Proceedings of the Conference on Discount Rates for the Evaluation of Public Private Partnerships. Queen's University, Kingston, Ontario.

TUD, 2004. Coolpack, V1.46. Mechanical Engineering, Technical University of Denmark, Lyngby, Denmark.

US EPA, 2002. EPA Air Pollution Control Cost Manual. EPA-452-02-001, sixth ed Office of Air Quality Planning and Standards.

Villaflor, G., Morales, G.V., Velasco, J., 2008. Variables Significativas del Proceso de Combustión del Gas Natural. Información Tecnológica 19 (4), 57-62.

Wang, et al., 2008. A fuzzy multi-criteria decision-making model for trigeneration system. Energy Policy 36 (10), 3823-3832.

Xunta de Galicia y Universidad de Santiago de Compostela, 2005. Autorización Ambiental Integrada: Guía de aplicación na industria da cerámica (in Galician). Consellería de Medio Ambiente, Spain.

ZareNezhad, B., Aminian, A., 2010. A multi-layer feed forward neural network model for accurate prediction of flue gas sulfuric acid dew points in process industries. Applied Thermal Engineering 30, 692-696. 